\title{
MARKET ACCESS, ECONOMIC GEOGRAPHY AND COMPARATIVE ADVANTAGE: AN EMPIRICAL ASSESSMENT
}

Donald R. Davis

David E. Weinstein

Working Paper 6787

http://www.nber.org/papers/w6787

\author{
NATIONAL BUREAU OF ECONOMIC RESEARCH \\ 1050 Massachusetts Avenue \\ Cambridge, MA 02138 \\ November 1998
}

Davis is grateful for the support of the National Science Foundation through the NBER, the Harvard Institute for International Development (HIID), and the Clark Fund. The authors are indebted to Tony Venables for invaluable suggestions. Jim Harrigan provided great insights and help with the data. Shangjin Wei likewise graciously provided data. Trevor Reeve provided outstanding research assistance. The views expressed in the paper are those of the authors and do not necessarily reflect those of the Federal Reserve, the National Bureau of Economic Research, or of other institutions providing support.

(C) 1998 by Donald R. Davis and David E. Weinstein. All rights reserved. Short sections of text, not to exceed two paragraphs, may be quoted without explicit permission provided that full credit, including $($ notice, is given to the source. 
Market Access, Economic Geography, and

Comparative Advantage: An Empirical Assessment

Donald R. Davis and David E. Weinstein

NBER Working Paper No. 6787

November 1998

JEL No. F1, D5, E1

\section{ABSTRACT}

The increasing returns revolution in trade is incomplete in an important respect - there exists no compelling empirical demonstration of the role of increasing returns in determining production and trade structure. One reason is that trade patterns of the canonical increasing returns models are a consequence simply of specialization, which all theories permit. Krugman (1980) shows that increasing returns models with costs of trade - economic geography - do allow a simple test: home market effects of demand on production. Davis and Weinstein (1996) reject the simple Krugman (1980) model on OECD data. Here we pair the model with a richer geography structure and find evidence of the importance of increasing returns, in combination with comparative advantage, in affecting OECD manufacturing production structure. The results underscore the importance of market access in implementing models of economic geography.

Donald R. Davis

Department of Economics

Harvard University

229 Littauer Center

Cambridge, MA 02138

and NBER

ddavis@fas.harvard.edu
David E. Weinstein

School of Business Administration University of Michigan

701 Tappan Street

Room 7207

Ann Arbor, MI 48109-1234

and NBER

weinstein@umich.edu 


\section{Comparative Advantage and Economic Geography Matter for Trade}

In the last two decades, an increasing returns "revolution" has transformed the field of international trade [Krugman (1990)]. The monopolistic competition models of Dixit and Stiglitz (1977), Krugman (1979), and Lancaster (1980) provided the foundation. The theory has earned enormous influence because of its promise to provide a unified account of a broad range of phenomena - intra-industry trade, the volume of North-North trade, the success of the gravity model of trade, the theory of multinationals, etc.

What has been singularly absent is a compelling empirical test that would launch the increasing returns trade hypothesis over the threshold from appealing theory to established fact. Of course, the increasing returns framework has inspired a great deal of empirical work. Yet the results have been, at best, inconclusive. One reason is that even the most interesting contributions fail to identify empirical features of trade patterns that would distinguish the models, so allow for hypothesis testing. Underlying this is the problem that the characteristic trade patterns often associated with the zero-trade-cost increasing returns models are a simple consequence of specialization. Yet all of the theories in contest - increasing returns or comparative advantage can account for such specialization and so the consequent trade patterns [Chipman (1992), Davis (1995, 1997), Deardorff (1998), Harrigan (1994)].

All is not hopeless. Inspired by Linder (1961), Krugman (1980) identifies a critical observation that distinguishes comparative advantage from increasing returns, provided that we restrict the latter to the class of models with trade costs that have come to be known as 
"economic geography."1 The test he proposes derives from a simple question: Can unusually strong demand for a good in a country lead that country to export the good? In a comparative advantage world, the answer is no; in an economic geography world the answer is yes. The phenomenon of unusually strong demand leading a good to be exported in a world of economic geography is known as the "home market effect."

This distills the clash between the two paradigms to the existence or absence of these home market effects, and so provides a sound conceptual basis for hypothesis tests. Moreover such a relation is quite unexpected within the framework of comparative advantage. Thus the existence of such home market effects would serve as prima facie evidence of the importance of economic geography and, by implication, increasing returns.

Davis and Weinstein (1996) implement Krugman's (1980) test on OECD data. The data strongly reject this model of economic geography in favor of a model of comparative advantage with costs of trade. Few industries conform to the economic geography model's predictions, and where these effects are evident their economic significance is scant.

This rejection of the simple Krugman (1980) model leads us to inquire whether a richer model of economic geography might yet reveal the characteristic home market effects. Krugman

${ }^{1}$ Krugman (1991) acknowledges the great difficulty in finding compelling evidence in favor of the new trade theories in their zero-trade-cost form. In fact, he argues that the main reason for considering models of economic geography is the "laboratory" they provide for distinguishing increasing returns and imperfect competition from the competitive constant returns theories. We agree.

${ }^{2}$ Alternative links between demand structure and exports have been hypothesized in a dynamic setting, as e.g. Bhagwati's (1982) "Biological” model of trade. We do not pursue these dynamic links in the present paper. 
(1991, p. x) assails the traditional economic geographers for their fascination with "a very narrow set of geometric tricks ...." In practice, this means that they investigated complex geographic relationships while treating the economics loosely, in particular ignoring issues of market structure [Krugman (1995)]. The decisive breakthrough in the new wave of theoretical work on economic geography is to reverse the emphasis - enriching the economic framework while greatly simplifying the geography in the models.

The decision to simplify the geography in the new theoretical models is strategic - to develop basic analytic insights on the role of market structure before returning to the intricate issues of a richer geography. Recent work considers a richer geography, notably in Krugman and Venables'(1995) elegant model of trade in a "seamless world." This marks a break from the treatment of countries as dimensionless points, rather thinking of them as fuzzy-edged agglomerations on a continuous surface. In important respects, the emphasis on the seamlessness of economic activity harks back to a traditional concern of economic geographers: the concept of "market access." The essential link is that economic distance is continuous rather than discrete.

This suggests the possibility that the empirical failure of the Krugman (1980) model on OECD data may well owe to its overly-simple model of geography. In turn, this suggests two research strategies. The first is to re-examine the problem while restricting the sample to countries or regions for which differential market access as a result of geography is likely to be relatively unimportant. Since it is plausible that differential market access is less pronounced for regions of a single country than for countries flung across the globe (as in our OECD sample), we pursue this strategy in a companion paper that examines the problem for forty regions of Japan [Davis and Weinstein (1998)]. 
In the present paper we choose to address the issue of a richer geography directly on international data. We caution the reader that no single analytic model contemplates even the minimal range of issues that the empirical researcher must confront. Hence, whereas our prior implementation of Krugman (1980) hews quite close to the analytic model, here we must take a larger step away from the formal framework.

For comparability, we implement this approach with the same OECD data used in Davis and Weinstein (1996). In that paper, the key parameter is the effect of idiosyncratic demand on production. A coefficient estimate above unity would indicate home market effects. That paper treats the relevant idiosyncratic demand as that of the nation state. The departure in the present paper is to pursue a two-step procedure. We estimate a gravity model to derive industry-specific parameters on the dissipation of demand across space. These economic distance parameters are then used to calculate the idiosyncratic demand, taking into account the derived demand from geographic neighbors, which then enters into tests for the home market effect as in our prior work.

The results we report here provide important evidence of the existence of home market effects. In turn, this suggests that increasing returns matter for the structure of international production and trade. The measured effects are significant in economic as well as statistical terms. Indeed, these results correlate closely with those we report in a companion study of Japanese regions [Davis and Weinstein (1998)].

Our results show that a model that draws on Helpman (1981) and Krugman (1980) provides a good depiction of OECD manufacturing. Comparative advantage does matter, both at the broad and fine industrial levels. The novel finding in the present study and its companion study 
is that whether one is considering the structure of production and trade across regions of a single country, or countries of the world, increasing returns and economic geography play a vital role.

\section{Prior Empirics of IRS and Trade}

The empirical trade literature features numerous papers attempting to examine or test increasing returns theories. Grubel and Lloyd's (1975) book demonstrating the quantitative importance of intra-industry trade marks the beginning of intense theoretical and empirical interest in this phenomenon. Following Grubel and Lloyd's path-breaking study, empirical researchers began investigating the importance of increasing returns both through calibration exercises [cf. Dixit (1988) and Baldwin and Krugman (1988)] and econometric investigations.

Within the latter genre, a number of papers stand out. Helpman's (1987) paper was among the first to derive testable implications of the theory and examine them on international data. The Helpman paper marks an important first step in establishing that certain observables, including gravity-type relationships, are consistent with the theory. Although Hummels and Levinsohn (1995) demonstrated that this consistency criterion might not be as strong as one might have hoped, the paper nonetheless is a milestone in deriving testable implications from the theory.

Later researchers sought to investigate other implications of the theory. Many of these studies are in line with the "estimate, don't test" injunction of Leamer and Levinsohn (1995). Among the most informative in this area are Harrigan's (1994) study of how the volume of trade varies with industry characteristics and Kim's (1995) study of the shifts in the geographic concentration of US manufacturing. As Harrigan notes, the "regression tests are purely descriptive," more concerned with uncovering important partial correlations than conducting 
specific hypothesis tests. Although Kim did estimate a specification that was designed to capture both scale effects and endowment effects, he too was quite cautious in the interpretation of the results, noting that "the Heckscher-Ohlin model is not given a completely fair representation [in this paper]." In an interesting recent effort, Hanson (1998) uses US regional wage data to estimate structural parameters of a Krugman model. Hanson finds that the estimated parameters have the right sign and tend to have magnitudes consistent with the economic geography model.

Very few papers, however, have attempted to nest an increasing returns model in a comparative advantage framework. ${ }^{3}$ One interesting effort in this regard is that of Antweiler and Trefler (1997). The paper nests increasing returns and comparative advantage into a common framework, estimating the degree of industry economies of scale. Antweiler and Trefler acknowledge a difficulty in distinguishing increasing returns from Ricardian technical differences, but argue that increasing returns is likely to be an important part of a full account.

The present paper explores a distinct approach to testing comparative advantage and increasing returns. A critical feature of the economic geography framework is the interaction of trade costs with increasing returns [cf. Fujita, Krugman and Venables (1997)]. Moreover the recent empirical literature has emphasized that the costs of trading across borders are far from

${ }^{3}$ The need for serious empirical work to articulate the relative importance of the various theories has been repeatedly emphasized by some of the principal developers of the new trade theory. For example, Grossman (1992, pp. 6, 13) writes that "To date, empirical work in this area is still in its infancy .... The next step surely must be a careful testing of the new theories. Empirical work has lagged in this area to the point where skeptics question whether the approach has testable implications." Similarly, Krugman (1994, pp. 9, 26-27) refers to the new trade theory as "an enormous theoretical enterprise with very little empirical confirmation," emphasizing that " ... there has not been any dramatic empirical confirmation of the models ...." In his survey of the empirical evidence regarding new trade theory, Krugman fails to cite a single econometric study in support of the increasing returns hypothesis. We hope that the present paper, in concert with other recent efforts, will begin to fill this gap. 
trivial, underscoring the importance of considering this analytic feature in structuring empirical work [cf. Engel and Rogers (1996), Helliwell (1996), and McCallum (1995)]. In contrast to Antweiler and Trefler, we make the sharp differences in the empirical predictions of the increasing returns and comparative advantage models in the presence of trade costs the centerpiece of our empirical analysis. Our work, however, differs importantly from that of Davis and Weinstein (1996) in that we no longer limit ourselves to considering demand deviations arising from purely national sources, but widen our concept of geography to allow for cross-country effects as well.

We draw several lessons from this brief survey. Each of these papers provides a structured way of thinking about the data, and so an interesting window on the determinants of production and trade structure. Incrementally they help to narrow the range of alternatives that may reasonably be contemplated. However all of the studies confront a difficult problem, viz. the limited data available for testing. One consequence is that it is impracticable to nest all potentially relevant hypotheses for a single critical test — one cannot hope to answer overly subtle questions. This in turn underscores the importance of the selection of hypotheses that will be considered. Subject to this, it likewise emphasizes the importance of working with an analytic structure that truly distinguishes the hypotheses in contest.

\title{
III. Theoretical Framework for Hypothesis Testing
}

\author{
A. The Home Market Effect
}


The broad outlines of our theoretical framework follow Davis and Weinstein (1996). The objective is to distinguish a world in which trade arises due to increasing returns as opposed to comparative advantage. This is very difficult if we focus on the class of zero transport cost increasing returns models deriving from Krugman (1979) and Lancaster (1979). However this is possible if we focus instead on the class of trade models that have come to be known as “economic geography," which interact increasing returns and trade costs in general equilibrium.

The crucial insight is from Krugman (1980, p. 955):

In a world characterized both by increasing returns and by transportation costs, there will obviously be an incentive to concentrate production of a good near its largest market, even if there is some demand for the good elsewhere. The reason is simply that by concentrating production in one place, one can realize the scale economies, while by locating near the larger market, one minimizes transport costs. This point ... is the basis for the common argument that countries will tend to export those kinds of products for which they have relatively large domestic demand. Notice that this argument is wholly dependent on increasing returns; in a world of diminishing returns, strong domestic demand for a good will tend to make it an import rather than an export. [italics added]

We begin by sketching the model of Krugman (1980). A more detailed discussion of the analytics is in Davis and Weinstein (1996). The model is one of monopolistic competition. There are two classes of goods, each with many varieties. All varieties are symmetric in production and demand. Each variety is produced under increasing returns to scale with a fixed cost and constant marginal costs in units of labor. Preferences are the iso-elastic Dixit-Stiglitz form. The novelty in Krugman's (1980) paper is the introduction to this framework of costs of trade in an iceberg form (for one unit of a good to arrive, $\tau>1$ units must be shipped). He further assumes that there are two countries which are mirror images of each other. They have the same labor forces. The difference lies in their demand structure. For simplicity, he assumes that consumers come in two 
types, each specialized to consume all varieties of only one of the two classes of goods. In addition, he assumes that the sole difference between the countries is that one country is predominantly populated by those who consume varieties of one of the classes of goods, and vice versa (in perfect mirror fashion) for the other. The symmetry insures factor price equalization in spite of the trade costs.

An important feature of the model is that the combination of constant mark-ups and free entry implies that in equilibrium output per firm is the same across markets in spite of the trade costs. This means that a full description of the equilibrium can be given by the number of varieties of each of the two types produced in each country. Let $\mu$ be the number of varieties of good $g$ produced at Home relative to those produced abroad. Let $\sigma<1$ be the ratio of demand for a typical import relative to a domestically produced variety in the same class. Let $\lambda$ represent the ratio of demanders for good $g$ at Home relative to the number in Foreign. Krugman shows that in the range of incomplete specialization, the relative production levels $\mu$ can be described as:

$$
\mu=\frac{\lambda-\sigma}{1-\lambda \sigma}
$$

When $\lambda=1$, demand patterns are identical and the countries produce the same number of varieties in each industry, leaving a zero net balance. This will play an important role when we turn to our empirical implementation as it suggests that predictions of production structure, ceteris paribus, should be centered around an even distribution of the industries across the countries. Idiosyncratic demand components will then explain deviations from this neutral production structure.

Moreover, we need to consider closely the way in which idiosyncratic demand components will translate into alterations in production structure. From above, and for the range of incomplete specialization for which these relations are valid, 


$$
\frac{\partial \mu}{\partial \lambda}=\frac{1-\sigma^{2}}{(1-\sigma \lambda)^{2}}>1
$$

Krugman emphasized that this will imply that countries with a large "home market" for a good will be net exporters of that good. For our purposes it is convenient to focus on an equivalent statement of this result that speaks directly to the implications for production. That is, idiosyncratic demand patterns (indexed by $\lambda$ ) have a magnified impact on production patterns. This will play a crucial role in our empirical implementation, helping to separate the influences of economic geography from that of comparative advantage.

Why does the home market effect arise? In the presence of trade costs, producers will have an incentive to locate near the larger source of demand. This is counterbalanced by the fact that as more and more producers leave the smaller market, those who remain experience the trade costs not only as an inhibition on their deliveries to the larger market, but also as protection against the many producers who have located in that larger market. Ex ante it may not seem obvious which of these influences will dominate. However, it is possible to show that if the share of varieties produced moved exactly one-for-one with the idiosyncratic demand that those producers located in the large country would have higher demand for their products than those located in the smaller market for that good. Since equilibrium requires that the derived demand be the same for all producers, this implies residual incentives for producers to move to the large market — hence the home market effect.

It is likewise important to think about why the home market effect does not arise in the conventional constant returns to scale comparative advantage framework. The logic turns out to be very simple. Consider a positive shock to the home demand structure for a good. Will this call 
forth additional local supply, and if so will supply move more than one-for-one (as required for the home market effect)? If the production set is strictly convex, additional supply of the good will be forthcoming only if its relative price rises. But then, provided the foreign export supply curve has the conventional positive slope, this will also call forth additional net exports from abroad. In such a case, the idiosyncratic demand will be partly met by additional local supply and partly by higher imports. Local supply, then, moves less than one-for-one with the idiosyncratic demand. In this conventional comparative advantage world, there is no home market effect.

Of course, Krugman (1980) cannot be taken straight to data. Such models of economic geography contemplate highly abstract worlds in order to provide clear theoretical insights. Even in such stark models, the inherent complexity of the problems frequently defies analytic solution. While the robustness of the home market effect has been explored along a variety of dimensions [e.g. Weder (1995)], there is no single fully-solved model that has simultaneously incorporated the myriad elements essential for empirical implementation. The approach of Davis and Weinstein $(1996,1998)$ is to hew as closely as possible to the theory, and so provide a highly-structured interpretation of the models. Where it is not possible to provide a full solution, we make what we consider the most sensible match between theory and specification.

\section{B. Economic Geography and Market Access}

Theory abstracts. The strategic choice for the theoretician is which dimensions to simplify and which to amplify. One could argue that much of the traditional economic geography made 
rather dramatic simplifications in the geographic structure analyzed. For example, the central place theory of industrial location is built on a featureless plain of homogeneous agricultural density. Losch suggests that this would give rise to hexagonal markets, and Christaller suggests further that there emerges a hierarchy of central places with interlaced markets [see e.g. the discussion in Krugman (1995)]. Yet — especially in light of what would follow — the emphasis on the simplifications of the geography in the early work is misplaced. They examine complex problems such as industrial location in a world of two dimensions and multiple agglomerations. Indeed, one could argue to the contrary that the distinctive aspect of their models is precisely the emphasis on important features of real geography

Krugman (1991, p. 5; 1995), while applauding the vision of those who pursued the problems of economic geography even as it was ignored by the mainstream of Anglo-American economics, nonetheless is critical of the research strategy:

"Much of the literature on industrial location ... [has] been obsessed with geometry ... while paying little or no attention to the problem of modeling markets. This is, to my mind, doing things in the wrong order, worrying about the details of a secondary problem before making progress on the main issue."

The decisive break in the new theoretical economic geography is to reverse this hierarchy — to start with a complete, if simple, economic model, and to be much less ambitious in terms of the real geography modeled. Thus, a large number of the contributions consider a world with only two locations, themselves treated as points in space [e.g. Krugman (1980, 1990), Krugman and Venables (1995)]. Having established a range of initial insights in these highly simplified geographic structures, the new literature (both open and closed economy) reintroduces at least some dimensions of geographical complexity. For example, Krugman (1993) considers the 
problem of city size and location in a model where potential sites are at discrete and symmetric points on a circle. More recent analytic work by Krugman and Venables (1995) considers a continuum of sites again arrayed on a circle — what they term the "seamless world." Fujita, Krugman, and Venables (1997) promises to reintroduce other real features of geography (rivers, etc.). Thus the stark simplifications of geography in the earliest models are now being amended, but these still fall short of the richness of geography in the earlier models, let alone the world that we live in.

This is a wonderfully fruitful strategy for theory. But it poses a dilemma for those who aim to implement the theory empirically. One would like to stay as close to the analytic models as possible, so that we may place a structural interpretation on the estimated coefficients. However, as we seek incrementally to incorporate greater geographic realism in the empirics, we are forced further from a direct implementation of the analytic models. Thus it is inevitable that tests of the theories are joint tests of the micro-structure of the models and the manner in which geography is modeled.

The geography implicit in Davis and Weinstein $(1996,1998)$ can be thought of as an effort to stay close to the analytic model of Krugman (1980). Where Krugman has two countries with fixed costs of trade between them, Davis and Weinstein have $\mathrm{N}$ countries, any pair of which have the same costs of trade between them. In geometric terms, this can be thought of as a hub and spoke system. All countries are located at the ends of the spokes, while trade between any pair must pass through the hub. A heuristic comparison of the models appears in Figure 1.

In the present paper, we take a step toward incorporating more "real world" geography into the model. In doing so, we necessarily take a step away from existing analytic models. We 
employ a gravity framework to allow the distinctive geographical positions of countries to affect their degree of market access, especially insofar as this affects the relative incentives for siting industry. This might be thought of as an asymmetric gravity-based model. A heuristic representation appears in Figure 2. We describe the details of the implementation below.

\section{Implementing the Search for Home Market Effects}

\section{A. Methodology}

We begin with a sketch of the theoretical framework that Davis and Weinstein (1996) develop in detail. The specification and data work consider three levels of product aggregation: Varieties, Goods, and Industries. Varieties play an important theoretical role within the model of economic geography. In the Dixit-Stiglitz (1977) formulation, they are the locus of increasing returns in production, as well as the elements across which consumers have a preference for variety. While they play an important theoretical role, we assume they exist at a greater level of disaggregation than exists in our data. Goods, in our formulation, can be thought of in two ways. Under the hypothesis of increasing returns, a good is a collection of a large number of varieties produced under monopolistic competition. It is at the goods level that differences in the composition of demand give rise to home market effects. By contrast, under the hypothesis of comparative advantage, a good is a traditional homogeneous commodity. Industries, in both frameworks, consist of a collection of goods produced using a common technology. In the comparative advantage framework, we interpret these as simple Leontief input coefficients. In the increasing returns framework, we assume that both fixed and marginal costs of all varieties of all 
goods within an industry use inputs in a fixed proportion. In our data work, industries and goods are typically 3- and 4-digit ISIC data respectively.

The null hypothesis that we consider is that comparative advantage determines production and trade. The particular model of comparative advantage that we implement is the so-called "square" Heckscher-Ohlin (HO) model, i.e. with equal numbers of goods and factors [cf. Ethier (1984)]. All countries share identical Leontief technologies of production, which are linearly independent, so that the technology matrix is invertible. Let $\mathrm{n}$ be an index of industries, $\mathrm{g}$ of goods, and c of countries. Let W stand for the whole world, and ROW stand for the rest of the world (excluding country c). Let $X_{g}^{n c}$ and $X_{g}^{n R O W}$ be total output in good g of industry n for country $\mathrm{c}$ and the rest of the world respectively. Let $\mathrm{V}^{\mathrm{c}}$ be the vector of endowments of country $\mathrm{c}$. Let $\Omega$ be the inverse of the technology matrix, and $\Omega_{\mathrm{g}}{ }^{\mathrm{n}}$ be the row corresponding to the $\mathrm{g}$ 'th good in industry $\mathrm{n}$. Then our Heckscher-Ohlin model of goods production is given by:

(1) $\quad X_{g}^{n c}=\Omega_{g}^{n} V^{c}$

The alternative that we consider is what we term the Helpman-Krugman specification. It is inspired by Helpman's (1981) integration of Heckscher-Ohlin with a zero transport cost model of monopolistic competition. But in place of the latter we substitute the Krugman (1980) model of economic geography.

Accordingly, we assume output structure is determined in two stages. We assume the Heckscher-Ohlin model determines the broad industrial structure of a country. Let $\bar{\Omega}_{n}$ be the n'th row of an inverse technology matrix for industry output, where the coefficients indicate average 
inputs at the equilibrium scale per variety (which is constant within an industry). Let $\mathrm{G}^{\mathrm{n}}$ be the number of products in industry $\mathrm{n}$. Then output in industry $\mathrm{n}$ in country $\mathrm{c}$ is given by:

(2) $\quad X^{n c}=\sum_{g=1}^{G_{n}} X_{g}^{n c}=\bar{\Omega}^{n} V^{c}$

While we assume endowments map perfectly to industry-level output, we also assume they tell us nothing about the composition of production across the goods within an industry. Since all varieties of all goods within an industry are assumed to use the same mix of factors, these may be thought of as a composite factor — an analogue to the single factor "labor" of Krugman (1980). Because of the Leontief technology assumption, resource constraints become industry-specific within a country. A heuristic diagram, a counterpart to the Helpman (1981) model, appears as Figure 3. Given endowments, we know the distribution of output between the $\mathrm{X}$ and $\mathrm{Y}$ industries. But this does not yet tell us how output will be distributed across goods within each industry.

We may think of the determination of the output of the various goods within an industry in two stages. Absent idiosyncratic elements of demand, each country allocates its resources across the goods within a particular industry in the same proportion as all other countries. This provides the country with a base level of production for each good in an industry that we denote SHARE. The second component arises when there are idiosyncratic elements of demand across the goods — what we term IDIODEM. These gives rise to home market effects, here a more than one-forone movements of production in response to idiosyncratic demand.

In order to make this precise, we must distinguish between a country's demand for a good produced in many locations, which we denote $D_{g}^{n c}$, from the derived demand facing producers in 
a particular locale which forms the basis for the construction of IDIODEM, the latter of which we denote $\tilde{D}_{g}^{n c}$. We may denote the correlate for the rest of the world as $\tilde{D}_{g}^{n R O W}$. Because output and demand shares figure prominently in our discussion, it is convenient to define some additional variables. Let $\gamma_{g}^{n c} \equiv \frac{X_{g}^{n c}}{X^{n c}}$ and $\tilde{\delta}_{g}^{n c} \equiv \frac{\tilde{D}_{g}^{n c}}{\tilde{D}^{n c}}$. With these definitions in hand, the specification may be written in a general form as:

$$
X_{g}^{n c}=\alpha_{g}^{n}+\beta_{1} S H A R E_{g}^{n c}+\beta_{2} I D I O D E M_{g}^{n c}+\epsilon_{g}^{n c}
$$

where

$$
\operatorname{SHARE}_{g}^{n c} \equiv \gamma_{g}^{n c} X^{n c}, \quad \text { IDIODEM } M_{g}^{n c} \equiv\left(\tilde{\delta}_{g}^{n c}-\tilde{\delta}_{g}^{n R O W}\right) X^{n c}
$$

IDIODEM is our measure of the extent of idiosyncratic derived demand. The term in parentheses measures the extent to which the relative demand for a good within an industry differs from that in the rest of the world. If all countries demand goods in the same proportion, then IDIODEM is identically zero. When relative demand for producers of a good in one country is higher (lower) than that in the rest of the world, IDIODEM is positive (negative). Multiplying this term by $X^{n c}$ gives IDIODEM the correct scale and units to include in the regression.

If instead we believe that endowments may matter for the structure of 4-digit production, then Davis and Weinstein (1996) show that an appropriate way of nesting the models is as follows:

$$
X_{g}^{n c}=\alpha_{g}^{n}+\beta_{1} \gamma_{g}^{n R O W} X^{n c}+\beta_{2}\left(\tilde{\delta}_{g}^{n c}-\tilde{\delta}_{g}^{n R O W}\right) X^{n c}+\Omega_{g}^{n} V^{c}+\epsilon_{g}^{n c}
$$

or

$$
X_{g}^{n c}=\alpha_{g}^{n}+\beta_{1} \operatorname{SHARE}_{g}^{n c}+\beta_{2} \text { IDIODEM }{ }_{g}^{n c}+\Omega_{g}^{n} V^{c}+\epsilon_{g}^{n c}
$$


The model allows us to use the estimate of $\beta_{2}$ to distinguish three hypotheses. In a frictionless world (comparative advantage or increasing returns), the location of demand does not matter for the pattern of production, so we would predict $\beta_{2}=0 .{ }^{4}$ When there are frictions to trade, demand and production are correlated even in a world of comparative advantage, reaching exactly one-for-one when the frictions force autarky. However production does not rise in a more than one-for-one manner. Accordingly, if we find $\beta_{2} \in(0,1]$, we conclude that we are in a world of comparative advantage with transport costs. Finally, in the world of economic geography, we do expect the more than one-for-one response, hence $\beta_{2}>1$. Summarizing, the estimate of $\beta_{2}$ allows us to distinguish three hypotheses:

$$
\begin{array}{ll}
\beta_{2}=0 & \text { Frictionless World (Comparative Advantage or IRS) } \\
\beta_{2} \in(0,1] & \text { Comparative Advantage with Frictions } \\
\beta_{2}>1 & \text { Economic Geography }
\end{array}
$$

These form the basis for our hypothesis tests.

Direct estimation of Equation (4) is not possible because of the simultaneity problem arising from having industry output on the right-hand side and the output of a good within that industry on the left. We can eliminate this simultaneity by remembering that, in our framework, endowments determine industry output. Using endowments as instruments for $X^{n c}$ eliminates the simultaneity problem.

${ }^{4}$ The inability of our framework to distinguish comparative advantage from increasing returns in the frictionless case is of little practical import. The data here will be seen to strongly reject the frictionless framework, consistent with work by McCallum (1995) and Engel and Rogers (1996). 
There are a number of ways in which we can estimate Equation (4) in addition to estimating the full system. If one believes that endowments do not matter at the goods level, then one can force $\Omega$ to equal zero for every factor and industry. In the absence of factor endowments, one should expect the coefficient on $\beta_{1}$ to equal unity. This is due to the fact that ceteris paribus one expects the share of goods production within an industry to be the same across countries. While Davis and Weinstein (1996) confirm this, the parameter often has much larger standard errors and deviates far from unity in specifications including endowments. ${ }^{5}$ This owes to the high degree of multicollinearity between SHARE (which is formed in part using endowment instruments) and the endowments. Since we found that the crucial coefficient on $\beta_{2}$ in specifications with endowments is largely invariant to the inclusion of SHARE, we dropped the latter from our specifications with endowments.

The main departure that we contemplate in this paper is the construction of IDIODEM. In Davis and Weinstein (1996), the demand employed in the construction of IDIODEM is simply equal to the demand for the good within a given country. However, as we noted earlier, this is

${ }^{5}$ Davis and Weinstein $(1996,1998)$ found that in specifications with endowments and SHARE, $\beta_{1}$ is negative and significant. This likely results from an identification problem that arises when we include SHARE and endowments. Since $\hat{X}^{n c}$ is a linear function of endowments, if there were no movement in $\gamma_{g}^{n R O W}$ across countries, SHARE would be perfectly collinear with endowments and we could not estimate a coefficient. This is what would have occurred if we had calculated SHARE using $\gamma_{g}^{n W}$ (where $\mathrm{W}$ indicates world values) instead of $\gamma_{g}^{n R O W}$. The linear relationship between endowments and $\hat{X}^{n c}$ means that we would obtain an identical coefficient if we replaced SHARE with $\left(\gamma_{g}^{n R O W}-\gamma_{g}^{n W}\right) \hat{X}^{n c}$. Identification here is achieved by examining the difference between $\gamma_{g}^{n R O W}$ and $\gamma_{g}^{n W}$. This is likely to produce a negative coefficient because the share of four-digit output in the rest of the world is likely to be below the world average precisely when output in a country is above average. 
not the appropriate measure of demand idiosyncracies relevant to local producers in a world in which real geography is asymmetric. The structure of demand in Germany and France affects the incentives for producers locating in Belgium more strongly than the demand in Japan and Australia. We must introduce these aspects of real world geography. They enter in the specification of $\tilde{D}_{g}^{n c}$.

The main question for empirics is how to estimate the effect of distance on demand. Leamer (1997) suggests using a parameter from a gravity equation to indicate the impact of distance on demand. Here we attempt a slightly more refined approach, one that allows each industry to have a different level of trade costs. Specifically, we assume that the volume of trade in industry $n$ between two countries $c$ and $c^{\prime}$ is described by the following equation:

$$
\ln \left(T_{c c^{\prime}}^{n}\right)=\phi+\lambda \ln \left(G N P_{c} G N P_{c^{\prime}}\right)+\psi \ln \left(D I S T_{c c^{\prime}}\right)+\eta_{c c^{\prime}}^{n}
$$

where $T_{c c^{\prime}}^{n}$ is the volume of trade in industry $n$ between countries $c$ and $\mathrm{c}^{\prime}, \mathrm{GNP}_{c}$ is the GNP of country $c$, DIST ${ }_{c c^{\prime}}$ is the distance between $c$ and $c^{\prime}$. The Greek letters are parameters to be estimated and $\eta$ is the normally distributed error term. ${ }^{6}$ Bergstrand (1990) shows that the gravity model has extremely good predictive power even on an industry level. This no doubt is a result of the high degree of specialization in international production. For our purposes, however, we want

${ }^{6}$ One may wonder why we did not include an adjacency term in the specification. At one point we tried this but for some sectors we obtained negative coefficients on the adjacency term. Since we have to assume that countries are adjacent to themselves, this resulted in countries sometimes having negative derived demand. Since this does not make any sense, we decided to leave the adjacency term out of the specification. 
to focus on the distance parameter. This coefficient measures the degree to which distance causes the demand for a product to decline.

Once we estimate this parameter we can then calculate the derived demand (domestic plus international) that a producer in a given location faces. Let this be given as $\tilde{D}_{g}^{n c}$. Let local demand in c for this type of good (from all locations) be $D_{g}^{n c}$. Then we may represent this derived demand for local producers as:

$$
\tilde{D}_{g}^{n c}=k_{g}^{n} \sum_{c^{\prime}} D_{g}^{n c^{\prime}} D I S T_{c c^{\prime}}^{\Psi_{n}}
$$

World demand is then

$$
\tilde{D}_{g}^{n W}=k_{g}^{n} \sum_{c, c^{\prime}} D_{g}^{n c} D I S T_{c c^{\prime}}^{\Psi_{n}}
$$

If we require that this redistribution of world demand does not change aggregate world demand, then this is equivalent to requiring that

$$
k_{g}^{n}=\frac{\sum_{c} D_{g}^{n c}}{\sum_{c, c^{\prime}} D_{g}^{n c} D I S T_{c c^{\prime}}^{\psi_{n}}}
$$

This transformation enables us to redistribute world demand in order to take into account the fact that demand in one country can spill over into another country. The only remaining question is how far countries are from themselves. We solve this in a standard way, following Leamer (1997). Assume all countries are circular in shape. If producers are evenly distributed across the circles, then the expected distance between any two randomly selected points equals 
the radius of the circle. In this case the distance a country is from itself equals the square root of its area divided by $\pi .^{7}$

\section{B. Data}

In order to allow comparability with Davis and Weinstein (1996) we use the same data set. ${ }^{8}$ Greater detail on the construction of the data set is available there. There is one small difference in the data we use in this paper and that used in our original work. For three sectors (other food products, rubber products, and professional and scientific equipment) BelgiumLuxembourg and Finland only report one four-digit sector within a three digit sector. The values Belgium-Luxembourg and Finland report seem exceptionally large in these sectors and lead us to suspect that data from other four digit sectors is included in these sectors. We therefore delete these industries from the data set. However, before doing so we re-ran our equations with and without these sectors and found that the results in Davis and Weinstein (1996) are robust to the inclusion of these three outliers.

${ }^{7}$ There is one other methodological difference between our approach and that of Davis and Weinstein $(1996,1998)$. In those papers, we postulate the form of the heteroskedasticity as arising from the following stochastic process:

$$
\operatorname{var}\left(\epsilon_{g}^{n c}\right)=v_{g}^{n} G N P_{c}^{\theta_{g}^{n}}
$$

where $v_{g}{ }^{n}$ and $\theta_{g}{ }^{n}$ are parameters. In Davis and Weinstein (1996) all of the $\theta_{g}{ }^{n}$ 's are positive, as one would expect. However, Reeve (1997) points out that in some of the most disaggregated runs the $\theta_{g}{ }^{n}$ 's are negative. We therefore follow Trefler (1995) and force all of the $\theta_{g}{ }^{n}$ 's to equal one. None of this qualitatively affects any of the results in either paper.

${ }^{8}$ The data set includes twenty-two countries. Thirteen countries provide both three- and four digit data [Australia, Belgium/Luxembourg, Canada, Finland, France, Germany, Italy, Japan, Netherlands, Norway, Sweden, UK, USA]. Nine countries provide only three-digit data [Austria, Denmark, Greece, Ireland, New Zealand, Portugal, Spain, Turkey, Yugoslavia]. 
In addition to the data from the Davis and Weinstein (1996) paper, we also use the OECD’s COMTAP bilateral import and export numbers as prepared by Harrigan (1993) and made available by Feenstra (1997). Country distance is measured as the distance between the major economic centers in two countries, and comes from Wei (1996). Measurements of how far countries are from themselves are taken from Leamer (1997).

\section{Estimates of The Gravity Equation}

The results of our gravity equation estimation appear in Table 1. Over all, the fits are quite reasonable. The gravity equations typically explain around half of the variance in bilateral OECD trade, and the coefficient on the product of the GNP's is close to unity as one would expect. More importantly for our purposes, the coefficient on distance is negative and significant in all specifications. Typically a 1 per cent increase in distance causes trade to decline by 1 per cent, although there is substantial variation in this estimate across goods. There seems to be a fair amount of variation in the magnitudes of the parameters on distance. Interestingly, food products seem least affected by distance, while sectors like transportation equipment and apparel are most affected. Most likely this is because the distance parameter is picking up an amalgam of effects. Traditional transportation costs proportional to weight-to-value ratios are no doubt present. But one should not forget that non-traditional costs such as informational and marketing costs are also likely to be significant for many manufactured goods [cf. e.g. Rauch (1996)].

The distance parameter estimates from these gravity equations permit us to formulate our new measure of idiosyncratic demand. Table 2 presents some sample statistics. We see that the typical four-digit sector is approximately one-quarter the size of a three digit sector. The 
magnitude of the demand deviation is perhaps the table's most striking feature. Overall, there is little variance in our measure of demand deviation. The ratio of four-digit to three-digit output seems to be within 0.22 of that in the rest of the world. In comparison with our previous measure in Davis and Weinstein (1996), both the range and the standard deviation of the demand deviation are approximately one-third the previous values. At first one might suspect that the reduced variance results simply from our having removed a few outliers. But this is not the case - even if we include the outliers, the standard deviation falls by half.

The key is the way in which market access is now allowed to affect the structure of idiosyncratic demand. Because of Belgium's proximity to France and Germany, the structure of the derived demand a Belgian producer faces is strongly affected by demand outside of Belgium. Hence, large idiosyncracies in Belgium's own demand are likely to be smoothed out by the demand in other countries. Such effects reduce the amount of variance in our idiosyncratic demand variable.

We would like to know what the relationship is between the idiosyncratic demand variable derived from the gravity equation and the original variable used in the Davis and Weinstein (1996) paper. IDIODEM itself is difficult to work with because it varies with industry size. However, if we divide IDIODEM by $\mathrm{X}^{\mathrm{nc}}$ we obtain a new variable, the demand deviation, which is much easier to handle because it is bounded between negative and positive one. In Figure 4, we plot the two demand deviation variables against each other. As one might expect, the two variables are positively and significantly correlated with each other. The major difference is that there is much more variation in the idiosyncratic country demands than in the gravity equation-based deviation 
variable. This is basically what one would expect given that country-level idiosyncratic demands cannot be perfectly correlated across countries.

We can provide an additional check that the derived idiosyncratic demands are sensible. It is quite plausible that large countries have important effects on the derived idiosyncratic demand of small neighboring countries, and much less plausible that the reverse holds. Hence we should expect that our new measure of IDIODEM tends to differ from that Davis and Weinstein (1996) employ more frequently for small than large countries. A rough check of this is to count how often the gravity equation transformation changes the demand deviation more than one standard deviation (based on the untransformed data, i.e. 0.11). We plot the number of times a country's demand deviation changes by more than one standard deviation against the log of the country's GNP. Figure 5 reveals that accounting for geography causes large changes in the demand deviation variable for small countries far more frequently than for large countries. The four smallest economies account for 40 per cent of all of the large changes in demand deviations, while the four largest economies account for only 13 per cent of these movements. If we focus on the extremes of the distribution, the picture is yet more stark. The two smallest economies, Finland and Norway, account for 27 per cent of the large variations and the two largest economies, Japan and the US, but 2 per cent. Clearly proximity to large economies matters more on average for small economies than large economies. This strikes us as quite reasonable and well within the spirit of geography models.

\section{Estimation}

\section{A. Pooling and Aggregation}


Our discussion makes a clear analytic distinction between various levels of aggregation varieties, goods, and industries. No such neat division exists in the data. Thus the level of aggregation at which to implement our methodology is a matter of judgment and subject to data availability. If data were not a constraint, our inclination would be to think of goods as being at a level of disaggregation greater than exists in the currently available data. Accordingly, in considering only this aspect of the problem, our preference is to work with the most disaggregated data available. We do, though, consider a case at a higher level of aggregation since this provides us with more observations and allows comparability with previous work.

A second important consideration is the extent to which we should pool observations across goods and industries. There is a clear advantage to pooling — it increases the number of observations. This is potentially important, since in our most disaggregated runs we will have only thirteen observations. However there is correlatively an important disadvantage of pooling - it forces us to impose more structure on the estimates, and so leads us further from the underlying analytic model. These include assumptions of common input proportions, demand symmetry, and equilibrium scale economies for all varieties of all goods within an industry. Ex ante it is difficult to know whether we should be happier with estimates in which the theoretical model is more appropriate but there are very few observations or the contrary case.

Our approach is to implement the estimation at a variety of levels of both pooling and aggregation. If home market effects exist, we would at least like to see some indication of their presence in the various exercises. However we should likewise be cognizant that since these place quite distinct constraints on the data, it will be asking too much to expect a perfect mapping among results from the varied runs. 
We pursue four estimation exercises. In three of these, the dependent variable is four-digit production, with the runs distinguished by the extent of pooling, while the fourth treats three-digit output as the dependent variable for individual industry runs. Consider first what we term the "pooled" run. This exercise pools all four-digit observations for the estimation of a single coefficient on IDIODEM. The great advantage of this exercise is that there are 650 observations. The disadvantages lie in that implicitly we must assume that either all industries are comparative advantage or all are economic geography, and that we must assume there is a common structure determining the coefficient on IDIODEM for all goods in all industries. We next move to the opposite extreme, that of individual "four-digit" good runs. The advantages of this exercise are that it is closest to the analytic structure we posit and that it allows the most detailed comparison across sectors of the presence or absence of home market effects. The disadvantage is that data availability implies there are only thirteen observations per four-digit sector. We next report an intermediate approach which pools all observations for four-digit goods within a three digit industry. We may term these "industry-pooled" runs. This approach trades off the advantages of the previous two exercises. It imposes less structure than the fully pooled runs, but typically has four times as many observations as the individual four-digit industry runs. This also suggests the downside, namely the fact that it forces us to impose some common structure within industries that may not be fully suggested by the results in the four-digit runs themselves.

Our final exercise returns to individual sectoral runs. The departure is that industries are now defined as two-digit output, and goods are three-digit output, and so are now the dependent variables. This has two important advantages. The first is that we do gain some observations relative to the four-digit runs, since twenty-two countries report the three-digit data. The second 
is that this structure and level of aggregation can be directly compared with results of Davis and Weinstein (1998) on Japanese regional data. There are three disadvantages to this exercise. The first is the loss of observations relative even to the industry-pooled runs. The second is that the additional observations relative to the four-digit runs come through the addition of countries that likely have lower quality data. Third, for related reasons, moving from the initial thirteen to twenty-two countries likely leads to a greater violation in our assumption of a common economic structure for all countries.

These four exercises provide different windows on the home market effect. As we have seen, each exercise has advantages and drawbacks. Hence to judge the results, we should not rely too heavily on any single exercise, but rather on the conjunction.

\section{B. Pooled Tests for the Home Market Effect}

Before running regressions, we feel it is informative to present a picture of what our data looks like. Equation 3 is specified as a multivariate regression, so is impossible to plot. However, if we constrain the coefficient on SHARE to equal unity, then simple algebraic manipulation enables us to rewrite Equation (3) as

$$
\gamma_{g}^{n c}-\gamma_{g}^{n R O W}=\frac{\alpha_{g}^{n}}{X^{n c}}+\beta_{2}\left(\tilde{\delta}_{g}^{n c}-\tilde{\delta}_{g}^{n R O W}\right)+\tilde{\epsilon}_{g}^{n c}
$$

If we plot the left-hand side of this equation against the term in parentheses, we can obtain an approximate idea of how production distortions move with demand distortions. What should we expect to see? In a frictionless comparative advantage world, one would expect the two variables to be uncorrelated. Frictions in a comparative advantage world would produce a positive 
correlation, but the slope of the line would be less than unity. Only in a world of home market effects should one see a positive correlation with a slope greater than unity.

We plot these in Figure 6 for the four-digit sectors. The data clearly seems to be arrayed along a line with a slope that is greater than unity. Indeed, the fitted line has a slope of 1.8, indicating that demand deviations typically produce more than proportional production deviations.

A more precise view of this relation comes from estimating Equation (4) under a variety of specifications. The results from these pooled regressions appear in Table 3. The most striking fact is that the coefficient on IDIODEM exceeds unity in all specifications. This indicates that on average there is a strong home market effect. In the typical OECD industry, if the derived demand deviation rises by 1 per cent, then output rises by 1.6 per cent. What is quite striking is that we obtain this result on the same data set used by Davis and Weinstein (1996). The crucial difference is that the relevant idiosyncratic demand now accounts for the real geography of the OECD economies.

A final econometric issue that we must address is simultaneity. Is idiosyncratic demand, as we posit, leading to a strong production response? Alternatively, is a level of production beyond that our model explains drawing in its wake idiosyncratic demand, creating only the appearance of home market effects? The ideal solution to this problem would be to find good instruments correlated with idiosyncratic demand, but not with output. Unfortunately we know of no such good instruments. Hence we cannot formally rule out the possibility that simultaneity influences our results. We can, though, take some steps to minimize its potential influence. Moreover we can give some reasons, based on the conjunction of our studies, to suggest that this is very likely not an appealing interpretation of our results. 
First, we construct the demand variable based on an average of demands in the countries ten to fifteen years prior to the estimation period. This removes simultaneity arising from contemporaneous correlations. Second, while we cannot instrument for IDIODEM, we can control for some of the potential price effects in the regression. In columns 2 and 4 we include a variable EXPORTD in our specification. EXPORTD is a dummy variable that equals one if the country is a net exporter of that commodity times the (instrumented) three digit output in that sector. EXPORTD controls for the fact that countries that are net exporters tend to have lower prices than countries that are net importers. As one can see the coefficient on EXPORTD is positive as one should expect, but it hardly affects the overall magnitude or significance of the coefficient on IDIODEM. The absence of a strong impact of controlling for whether the country is a net exporter or not makes it less likely that price movements associated with being a net exporter or importer of a commodity are driving our results.

Finally, we need to think more closely about whether it is attractive to interpret our results as arising from simultaneity. The story would need to go something as follows: While our model does a good job of predicting the pattern of production, it is surely less than perfect. Indeed, there could be some systematic influences on the pattern of production left out, as for example Ricardian technical differences across countries. Hence a country or region may have a high level of production of a good for reasons outside the model. In turn, this unusually high production may suggest lower prices for the associated good, so lead idiosyncratic demand to respond to the production in a less than one-for-one manner. Thus the argument would be that by reversing the direction of true causality, we find home market effects of production responding more than onefor one with idiosyncratic demand. 
The issue is whether this interpretation is attractive in light of the various investigations we have pursued of the home market effect. It is straightforward to show that under the hypothesis that production patterns are driven by comparative advantage, plausible assumptions lead one to conclude that the potential upward simultaneity bias in $\beta_{2}$ would diminish in the present paper relative to Davis and Weinstein (1996) because output is likely to have a much smaller effect on derived demand than on local demand. ${ }^{9}$ Since the estimated coefficient in that paper was 0.3 , this alone would suggest that simultaneity is not the likely cause of our finding of home market effects.

\section{The Home Market Effect in Industry Runs}

Having examined this by pooling all four-digit observations, we now move to the opposite extreme, considering each four-digit sector on its own. The results appear in Table 4. Because there are very few degrees of freedom, it is quite difficult to obtain statistical significance in these equations. Even so, we find that half of the sectors have coefficients on IDIODEM that are larger than unity and of these eleven are significantly greater than unity. By comparison, Davis and Weinstein (1996) only found half as many coefficients larger than unity and hardly any that are

\footnotetext{
${ }^{9}$ The story would specify an additional relation between idiosyncratic demand and production as follows: IDIODEM $=\omega X_{g}^{n c}+\eta_{D}$. For $\omega,(0,1)$, it is straightforward to show that a sufficient condition for the degree of bias to be increasing in $\omega$ is that $\beta_{2}<1$, i.e. that we are in a world of comparative advantage. The final step would be to note that the relevant $\omega$ is likely to be lower in the present work than in Davis and Weinstein (1996), since local demand is plausibly more strongly related to local production than is a weighted average of local and rest-ofworld demand.
} 
significant. This suggests that in our data, some industries are constant and others increasing returns to scale. ${ }^{10}$ Home market effects are very much in evidence.

One way to increase the number of degrees of freedom relative to the four-digit runs is to conduct industry-pooled estimation. This pools the four-digit observations within each three-digit industry, but allow the coefficient on IDIODEM to vary across three-digit industries. Relative to the fully-pooled runs, this allows us to relax the assumption that three-digit industries must either all be comparative advantage or all exhibit increasing returns. The results are presented in Table 5. In similar runs, Davis and Weinstein (1996) found that less than one-fifth of all sectors had point estimates above unity. Here, using our new measure of market access, we now find that over half of the industries exhibit home market effects. Furthermore, while the earlier study found that none of the point estimates were significantly larger than unity, we now find that four of our coefficients have this property. Moreover, while Davis and Weinstein (1996) rejected home market effects in two-thirds of the three-digit sectors, we now reject economic geography only in two sectors, other chemicals and non-electrical machinery.

One word of caution is in order. Looking at the sectors, it is somewhat disappointing that sectors like electrical machinery and transportation equipment do not have point estimates that exceed unity. A likely explanation is imprecision of the estimates. In both of these sectors, the standard errors are so large that we cannot reject home market effects. Indeed the four-digit runs presented in Table 4 indicate that in half the sectors within these industries (radio, television and

${ }^{10}$ More subtle problems arise if individual industries themselves are composed of both IRS and CRS goods. In alternative frameworks, Krugman (1980), Krugman and Venables (1995) and Davis (1998) address this problem. The various contributions stress the potential role of absolute market size and the cross-good structure of trade costs in determining industrial structure. This remains an important direction for further empirical study. 
communication equipment, electrical appliances and housewares, and motor vehicles), we do obtain point estimates for IDIODEM that exceed one.

Hence we conclude that, these problems notwithstanding, relative to previous work these results do represent a striking degree of support for the economic geography paradigm. Most sectors exhibit home market effects. Those that don't have point estimates that are typically measured imprecisely.

It is useful to compare these results to those in our companion study on Japanese regional data. There we also found significant home market effects. Unfortunately, it is difficult to match our new results with those of Davis and Weinstein (1998) because that paper used Japanese data at a different level of aggregation. However, if we aggregate the data so that we assume industries are defined at the two-digit ISIC and goods at the three-digit ISIC, then we have a roughly comparable level of aggregation.

There are several issues to bear in mind about increasing the level of aggregation. Because more countries report three-digit production data than four-digit, we have more degrees of freedom than on the four-digit runs. But the higher level of aggregation means that we increase the chance that we are pooling sectors that differ in many respects, including factor intensity. This may interfere with the operation of home market effects. For example, while it is plausible that high demand for motor vehicles might cause specialization in motor vehicles as opposed to motorcycles, it is less plausible that countries with high demand for transport equipment are less likely to produce precision instruments. On Japanese data, where we had compatible technology matrices, we could circumvent this problem by aggregating according to technological similarity, but on international data, this is not possible. Furthermore, we are faced with the problem that the 
variance in demand deviations shrinks at higher levels of aggregation. When we move from fourto three-digit data, the variance in our demand deviation variable falls by a factor of two for the countries for which we have comparable numbers. By comparison, Japanese regions had a demand deviation variance that was comparable to international four-digit data. Finally the inclusion of countries like Turkey and Yugoslavia in the three-digit sample probably exacerbates problems such as measurement error.

These reasons may help explain why Davis and Weinstein (1996) found a smaller impact of demand deviations on production deviations on more aggregated data. Nevertheless, since we did find evidence of home market effects at a higher level of aggregation on Japanese data (albeit with more than twice the number of degrees of freedom), it may be useful to compare those results with our international results at a higher level of aggregation.

We present the results from goods-level estimation at the three-digit level in Table 6. Although only one sector, textiles, exhibits a coefficient on IDIODEM that is significantly larger than unity, 9 out of our 26 sectors have point estimates in excess of unity. By comparison, in Davis and Weinstein (1998), 9 out of 19 sectors had point estimates larger than unity and 8 out of these 9 were significant. No doubt many of the reasons that we have highlighted above explain the relative imprecision of our international results. ${ }^{11}$ Even so, there is a fair amount of overlap between the two sets of results. If we restrict attention to the 14 sectors that appear in both the

${ }^{11}$ It should also be emphasized that the lower trade costs and greater factor mobility within a country, rather than across countries, is likely to make for stronger home market effects. This may also help to account for the greater number of significant home market effects in the regional data. 
international and regional data sets, ${ }^{12}$ we find that seven have $\beta_{2}$ 's that are significantly larger than unity in the Japanese data and five have point estimates larger than unity in the international data. Interestingly, four of the five international sectors that come up as having home market effects textiles, iron and steel, transportation equipment, and precision instruments — are among the seven sectors that also have measurable home market effects in the Japanese data. Although the large standard errors in these industry runs make it difficult to make strong statements, there is a striking degree of overlap. Furthermore, the fact that these sectors have often been presented as canonical examples of economic geography by Krugman (1991) and others bolsters the plausibility of our point estimates.

Returning to our individual four-digit sector runs, we next examine the issue of economic significance. Here we consider $\beta$-coefficients, which indicate how much a one standard deviation movement in the independent variable moves the dependent variable. Over all, our estimates for the pooled specification indicate that a one-standard-deviation movement in idiosyncratic demand moves production by about 0.15 standard deviations. While quite modest, it is still three times larger than the estimate in Davis and Weinstein (1996). However, since we are probably dealing with a mix of sectors, only some of which are monopolistically competitive, it makes sense to calculate these coefficients on a sector-by-sector basis.

12 This entails the removal of sectors Food Products, Beverage Industries, Tobacco, Leather Products, Footwear, Industrial Chemicals, Other Chemicals, Petroleum Refining, Plastic products nec, Pottery, China, and Earthenware, Glass and Glass Products, and Other NonMetallic Mineral Products (ISIC industries 311, 313, 314, 323, 324, 351, 352, 353, 356, 361, 362, and 369) from the international data and Chemicals, Petroleum and Coal Products, StoneClay-Glass, and Other Manufacturing from the Japanese data. 
We present the $\beta$-coefficients for four-digit goods in Table 7. They indicate that in many sectors the home market effect is extremely important. For example in electrical machinery sectors, we obtain $\beta$-coefficients that are typically in the 0.9 range - indicating that the absorption linkage to production is very important. Overall, in the sectors where we detect coefficients on idiosyncratic demand that are larger than unity, $\beta$-coefficients are typically around 0.5 .

A second way to obtain a sense of how important economic geography is to OECD production is to examine the relative sizes of the sectors for which $\beta_{2}$ is larger than unity. ${ }^{13}$ At the four-digit level, of the 50 sectors for which we have data, the sectors with coefficients on IDIODEM exceeding unity account for 64 per cent of the total output. Repeating this exercise for the three-digit sectors, where we have 22 countries and all manufacturing output for each country, reveals that 50 per cent of all manufacturing production is governed by economic geography. This indicates that the sectors that appear to have home market effects account for a majority of manufacturing output.

We interpret these results as important support for the proposition that economic geography does matter for international specialization. Our results build on our earlier work by highlighting a key feature of the economic geography model: market access. It is this new implementation of the theory that we find to be critical in identifying home market effects.

${ }^{13}$ One cannot infer from these figures that increasing returns accounts for corresponding shares of the volume of trade. Our model is of a trading world, and it is designed to identify the economic forces that determine production and trade. But the direct object of estimation is production rather than trade. A complete answer to the relative role of increasing returns and comparative advantage in determining the volume of trade is beyond the scope of this paper. The role of increasing returns in the latter question could in principle be higher or lower than its role in affecting production structure. 


\section{Conclusion}

The increasing returns revolution in trade is now nearly two decades old. Its appeal and influence have been great owing to its ability to provide a simple and unified account of a wide variety of phenomena acknowledged to be important in modern trade relations. Yet the existing empirical literature offers no compelling test of the theory. For an empirical test to be compelling, it must identify a feature that starkly separates the theories in contest. Yet existing empirical work fails in this regard. In large measure this is due to the fact that the trade patterns characteristic of the zero-trade-cost version of the theory are a consequence of specialization only. And all of the theories in contest can account for specialization.

Krugman (1980) proposes a test that can distinguish comparative advantage from increasing returns, if we restrict the latter to the realistic variant in which there are costs of trading across borders - a class of models that has come to be termed economic geography. The distinctive element of the economic geography setting is the existence of home market effects, the magnified impact of idiosyncratic demand on production.

In Davis and Weinstein (1996) we test Krugman's hypothesis on OECD data in a symmetric hub-and-spoke variant of Krugman's model. The data reject the hypothesis. Few sectors exhibit the characteristic home market effects, and where such effects are identified, their economic significance is scant.

The present paper re-examines the problem using precisely the same OECD data as in Davis and Weinstein (1996). The decisive departure in the present paper is the introduction of a richer geographical structure, which brings to the fore the issue of market access. A gravity model is used to estimate the effects of distance on demand. Thus the degree of integration is allowed to 
differ by country pair and industry. These estimates are used to construct the idiosyncratic demand that enters our tests for home market effects.

The results provide support for the economic geography hypothesis of the existence of home market effects. Hence they also provide important evidence on the role and importance of increasing returns in determining production structure for the OECD. The fact that home market effects are so unexpected in the traditional comparative advantage theories makes these results particularly striking. Moreover, findings of similar home market effects in a companion study of 40 Japanese regions in Davis and Weinstein (1998) bolster these results on the OECD.

The broad picture that emerges draws on insights from Helpman (1981) and Krugman (1980). Comparative advantage matters both in affecting the broad and fine industrial structure. Even at the four-digit level, from one-third to one-half of OECD manufacturing output seem to be governed by simple comparative advantage. However increasing returns also play a vital role, in the particular form known as economic geography. These have measurable effects on production structure for as much as one-half to two-thirds of OECD manufacturing output. Finally, we saw that the key to identifying these effects is to introduce more geographical realism into our models of production and trade. 


\section{References}

Antweiler, Werner and Daniel Trefler (1997) "Increasing Returns and all That," mimeo.

Baldwin, Richard E. and Paul R. Krugman (1988) "Market Access and International Competition: A Simulation Study of 16K Random Access Memories," in Robert C. Feenstra, Empirical Methods for International Trade, Cambridge: MIT Press; reprinted in Gene M.Grossman, (1992) ed. Imperfect Competition and Trade: Selected Readings, Cambridge: MIT Press.

Bergstrand, Jeffrey H. (1990) "The Heckscher-Ohlin-Samuelson Model, the Linder Hypothesis and the Determinants of Bilateral Intra-industry Trade," Economic Journal, 100(403), pp. 1216-29.

Bhagwati, Jagdish N. (1982) "Shifting Comparative Advantage, Protectionist Demands, and Policy Response," in Jagdish N. Bhagwati, ed. Import Competition and Response," Chicago: U. of Chicago Press.

Chipman, John S. (1992) "Intra-Industry Trade, Factor Proportions and Aggregation," in Economic Theory and International Trade: Essays in Memoriam, J. Trout Rader, NY: Springer-Verlag.

Davis, Donald R. (1995) “Intra-Industry Trade: A Heckscher-Ohlin-Ricardo Approach,”, Journal of International Economics, 39:3-4, November.

Davis, Donald R. (1997) "Critical Evidence on Comparative Advantage? North-North Trade in a Multilateral World.” Journal of Political Economy, October.

Davis, Donald R. (1998) “The Home Market, Trade, and Industrial Structure,” forthcoming American Economic Review.

Davis, Donald R., David E. Weinstein, (1996) "Does Economic Geography Matter for International Specialization?” mimeo, NBER Working Paper \# 5706, August 1996.

Davis, Donald R., David E. Weinstein, (1998) "Economic Geography and Regional Production Structure: An Empirical Investigation," forthcoming, European Economic Review.

Davis, Donald R., David E. Weinstein, Scott C. Bradford and Kazushige Shimpo (1997) "Using International and Japanese Regional Data to Determine When the Factor Abundance Theory of Trade Works," American Economic Review, 87, pp. 421-446.

Deardorff, Alan V. (1998) "Determinants of Bilateral Trade: Does Gravity Work in a Neoclassical World?" in Jeffrey Frankel, ed., Regionalization of the World Economy, Chicago: U. of Chicago and NBER.

Dixit, Avinash K., and Stiglitz, Joseph E. (1977) "Monopolistic Competition and Optimum Product Diversity," American Economic Review 67 (3), 297-308.

Dixit, Avinash K., and Norman, Victor (1980) Theory of International Trade, Cambridge: Cambridge U. Pr.

Dixit, Avinash K.(1988) “Optimal Trade and Industrial Policies for the US Auto Industry," in Robert C. Feenstra, Empirical Methods for International Trade, Cambridge: MIT Press; reprinted in Gene M.Grossman, (1992) ed. Imperfect Competition and Trade: Selected Readings, Cambridge: MIT Press.

Engel, Charles and John H. Rogers (1996) "How Wide is the Border?" American Economic Review, December.

Ethier, Wilfred J. (1984) "Higher Dimensional Issues in Trade Theory," in Ronald W. Jones and Peter B. Kenen, eds. Handbook of International Economics, vol. 1, New York: NorthHolland. 
Feenstra, Robert C. (1996) “U.S. Imports, 1972-1994: Data and Concordances,” NBER \#5515, and NBER Trade Database, Disk 1.

Fujita, Masahisa, Paul R. Krugman, and Anthony J. Venables (1997), “The Spatial Economy: Cities, Regions, and International Trade," mimeo.

Grossman, Gene M., (1992) ed. Imperfect Competition and Trade: Selected Readings, Cambridge: MIT Press.

Grubel, H.G. and P.J. Lloyd (1975) Intra-Industry Trade: The Theory and Measurement of International Trade in Differentiated Products, New York: John Wiley and Sons.

Harrigan, James (1993) “OECD Imports and Trade Barriers in 1983," Journal of International Economics, August.

Harrigan, James (1994) "Scale Economies and the Volume of Trade," Review of Economics and Statistics, 76:2.

Harrigan, James (1995) "Factor Endowments and the International Location of Production: Econometric Evidence from the OECD, 1970-1985," Journal of International Economics.

Harrigan, James (1997) “Technology, Factor Supplies and International Specialization: Testing the Neoclassical Model," American Economic Review, 87, pp. 475-494.

Helliwell, John F.(1996) ?Do National Borders Matter for Quebec's Trade?" University of Western Ontario, Papers in Political Economy, 74, May.

Helpman, Elhanan (1981) "International Trade in the Presence of Product Differentiation, Economies of Scale and Monopolistic Competition: A Chamberlin-Heckscher-Ohlin Approach," Journal of International Economics, 11:3.

Helpman, Elhanan (1988) "Imperfect Competition and International Trade: Evidence From Fourteen Industrial Countries," in A. Michael Spence and Heather Hazard, eds., International Competitiveness, NY: Ballinger Publishing.

Helpman, Elhanan and Krugman, Paul (1985) Market Structure and Foreign Trade, Cambridge: MIT Press.

Hummels, David, and Levinsohn, James (1995) "Monopolistic Competition and International Trade: Reconsidering the Evidence," Quarterly Journal of Economics, Vol. CX, August, pp. 799-836.

Kim, Sukkoo (1995) "Expansion of Markets and the Geographic Distribution of Economic Activities: The Trends in US Regional Manufacturing Structure, 1860-1987," Quarterly Journal of Economics, 40, pp. 881-908.

Krugman, Paul R. (1980) "Scale Economies, Product Differentiation, and the Pattern of Trade," American Economic Review, 70, 950-959.

Krugman, Paul R. (1990) "Introduction," Rethinking International Trade, Cambridge: MIT.

Krugman, Paul R. (1991) Geography and Trade, Cambridge: MIT.

Krugman, Paul R. (1993) "On the Number and Location of Cities," European Economic Review, 37: 2-3, April.

Krugman, Paul R. (1994) "Empirical Evidence on the New Trade Theories: The Current State of Play," in New Trade Theories: A Look at the Empirical Evidence, London: Center for Economic Policy Research.

Krugman, Paul R. (1995) Development, Geography, and Economic Theory, Cambridge: MIT Pr. Krugman, Paul R., and Anthony J. Venables (1995) "Globalization and the Inequality of Nations," Quarterly Journal of Economics, 110(4), pp. 857-80. 
Krugman, Paul R. and Anthony J. Venables (1995) "The Seamless World: A Spatial Model of International Specialization,” NBER Working Paper \#5220, August.

Lancaster, Kelvin, "Intra-Industry Trade Under Perfect Monopolistic Competition, " Journal of International Economics 10 (1980) 151-175.

Leamer, Edward (1984) Sources of International Comparative Advantage, Cambridge: MIT Press.

Leamer, Edward and James Levinsohn (1995) "International Trade Theory: The Evidence" in Gene Grossman and Kenneth Rogoff, eds., Handbook of International Economics, vol. 3, New York: Elsevier.

Leamer, Edward (1997) "Access to Western Markets and Eastern Effort," in Salvatore Zecchini, ed., Lessons from the Economic Transition, Central and Eastern Europe in the 1990s, Dordrecht: Kluwer Academic Publishers, 1997, pp. 503-526.

Linder, Staffan Burenstam (1961) An Essay on Trade and Transformation, NY: John Wiley and Sons.

McCallum, John (1995) "National Borders Matter: Canada-US Regional Trade Patterns," American Economic Review, 85:3.

Rauch, James E. (1996) “Networks Versus Markets in International Trade," NBER \# 5617, June.

Weder, Rolf (1995) "Linking Absolute and Comparative Advantage to Intra-Industry Trade Theory," Review of International Economics, 3:3, October.

Wei, Shang-Jin (1996) "Intra-National versus International Trade: How Stubborn are Nations in Global Integration?” NBER Working Paper \#5531. 


\section{Table 1}

\section{Gravity Equation Estimates}

157 Observations: 157, Standard Errors below estimates

\begin{tabular}{|c|c|c|c|c|}
\hline Industry Name & $\mathbf{R}^{2}$ & Cons. & GDP Product & Distance \\
\hline \multirow{2}{*}{ Food Products } & 0.51 & -11.55 & 0.68 & -0.48 \\
\hline & & 2.52 & 0.06 & 0.10 \\
\hline \multirow[t]{2}{*}{ Beverage Industries } & 0.53 & -25.43 & 1.04 & -0.82 \\
\hline & & 3.76 & 0.09 & 0.15 \\
\hline \multirow[t]{2}{*}{ Tobacco Manufactures } & 0.47 & -31.47 & 1.18 & -1.15 \\
\hline & & 5.09 & 0.12 & 0.20 \\
\hline \multirow[t]{2}{*}{ Textiles } & 0.58 & -11.12 & 0.70 & -0.71 \\
\hline & & 2.43 & 0.06 & 0.10 \\
\hline \multirow[t]{2}{*}{ Wearing Apparel } & 0.72 & -17.75 & 1.01 & -1.48 \\
\hline & & 2.95 & 0.07 & 0.12 \\
\hline \multirow[t]{2}{*}{ Leather Products } & 0.65 & -18.64 & 0.93 & -1.14 \\
\hline & & 2.97 & 0.07 & 0.12 \\
\hline \multirow[t]{2}{*}{ Footwear } & 0.60 & -22.85 & 1.08 & -1.41 \\
\hline & & 3.93 & 0.09 & 0.15 \\
\hline \multirow[t]{2}{*}{ Wood and wood products } & 0.51 & -16.50 & 0.90 & -1.22 \\
\hline & & 4.04 & 0.10 & 0.16 \\
\hline \multirow{2}{*}{ Furniture and fixtures } & 0.67 & -33.25 & 1.28 & -1.02 \\
\hline & & 3.50 & 0.08 & 0.14 \\
\hline \multirow[t]{2}{*}{ Paper and paper products } & 0.46 & -8.87 & 0.75 & -1.25 \\
\hline & & 4.06 & 0.10 & 0.16 \\
\hline \multirow[t]{2}{*}{ Printing and publishing } & 0.65 & -27.17 & 1.09 & -0.83 \\
\hline & & 3.05 & 0.07 & 0.12 \\
\hline \multirow[t]{2}{*}{ Industrial chemicals } & 0.71 & -19.12 & 0.98 & -0.94 \\
\hline & & 2.55 & 0.06 & 0.10 \\
\hline \multirow[t]{2}{*}{ Other chemical products } & 0.62 & -26.94 & 1.09 & -0.67 \\
\hline & & 3.11 & 0.07 & 0.12 \\
\hline \multirow[t]{2}{*}{ Petroleum refineries } & 0.64 & -21.92 & 1.15 & -1.66 \\
\hline & & 4.06 & 0.10 & 0.16 \\
\hline \multirow{2}{*}{ Rubber products } & 0.70 & -26.34 & 1.10 & -0.90 \\
\hline & & 2.79 & 0.07 & 0.11 \\
\hline \multirow[t]{2}{*}{ Plastic products nec } & 0.66 & -22.90 & 0.99 & -0.85 \\
\hline & & 2.77 & 0.07 & 0.11 \\
\hline
\end{tabular}




\section{Table 1 (Cont.)}

\begin{tabular}{|c|c|c|c|c|}
\hline Industry Name & $\mathbf{R}^{2}$ & Cons. & GDP Product & Distance \\
\hline \multirow{2}{*}{$\begin{array}{l}\text { Pottery, china and } \\
\text { earthenware }\end{array}$} & 0.64 & -30.77 & 1.13 & -0.70 \\
\hline & & 3.14 & 0.07 & 0.12 \\
\hline \multirow[t]{2}{*}{ Glass and glass products } & 0.64 & -23.63 & 0.99 & -0.77 \\
\hline & & 2.85 & 0.07 & 0.11 \\
\hline \multirow{2}{*}{$\begin{array}{l}\text { Other non-metallic mineral } \\
\text { products }\end{array}$} & 0.64 & -23.85 & 1.03 & -0.92 \\
\hline & & 3.04 & 0.07 & 0.12 \\
\hline \multirow[t]{2}{*}{ Iron and steel } & 0.74 & -21.76 & 1.13 & -1.42 \\
\hline & & 2.89 & 0.07 & 0.11 \\
\hline \multirow[t]{2}{*}{ Non-ferrous metals } & 0.69 & -25.15 & 1.17 & -1.32 \\
\hline & & 3.29 & 0.08 & 0.13 \\
\hline \multirow[t]{2}{*}{ Fabricated metal products } & 0.69 & -18.99 & 0.93 & -0.87 \\
\hline & & 2.48 & 0.06 & 0.10 \\
\hline \multirow[t]{2}{*}{ Machinery except electrical } & 0.64 & -22.49 & 1.04 & -0.75 \\
\hline & & 2.93 & 0.07 & 0.11 \\
\hline \multirow[t]{2}{*}{ Electrical machinery } & 0.67 & -25.27 & 1.10 & -0.77 \\
\hline & & 2.89 & 0.07 & 0.11 \\
\hline \multirow[t]{2}{*}{ Transport equipment } & 0.75 & -35.35 & 1.41 & -0.99 \\
\hline & & 3.09 & 0.07 & 0.12 \\
\hline Professional and scientific & 0.65 & -29.46 & 1.13 & -0.53 \\
\hline Equipment & 2.98 & 0.07 & 0.12 & \\
\hline
\end{tabular}


Table 2

Sample Statistics

\begin{tabular}{|l|r|r|r|r|}
\hline \multicolumn{1}{|c|}{ Variable } & \multicolumn{1}{c|}{ Mean } & \multicolumn{1}{c|}{ Std Dev } & \multicolumn{1}{c|}{ Minimum } & \multicolumn{1}{c|}{ Maximum } \\
\hline IDIODEM/X3 & 0.00 & 0.04 & -0.22 & 0.22 \\
\hline SHARE/X3 & 0.25 & 0.20 & 0.01 & 0.88 \\
\hline Capital & 785511000 & 1009220000 & 91670300 & 3512070000 \\
\hline Unskilled Labor & 20763 & 23547 & 1796 & 79190 \\
\hline Educated Labor & 5287 & 10145 & 243 & 37610 \\
\hline Land & 26480 & 51487 & 771 & 189799 \\
\hline Fuel & 239358 & 520333 & 22 & 1935810 \\
\hline Real GDP & 709383000 & 1054510000 & 59084700 & 3962220000 \\
\hline
\end{tabular}


Table 3

Pooled Runs

Dependent Variable is 4-Digit Production (Standard Errors below estimates)

$\begin{array}{lllll} & 1 & 2 & 3 & 4 \\ \text { IDIODEM } & 1.67 & 1.67 & 1.57 & 1.57 \\ & 0.05 & 0.05 & 0.10 & 0.10 \\ \text { SHARE } & 0.96 & 0.92 & & \\ & 0.01 & 0.02 & & 0.01 \\ \text { EXPORTD } & & 0.07 & & 0.04 \\ & & 0.02 & & \text { Yes } \\ \text { FACTORS } & \text { No } & \text { No } & \text { Yes } & 650\end{array}$

(Standard errors are below estimates) 
Table 4

Individual Four-Digit Runs

(Std. Errors Below Estimates)

Number of Observations $=13$

\begin{tabular}{|c|c|c|c|c|c|}
\hline Ind & Adj. $R^{2}$ & IDIODEM & Ind & Adj. $R^{2}$ & IDIODEM \\
\hline 3111 & 0.68 & $\begin{array}{l}3.45 \\
1.77\end{array}$ & 3215 & 0.95 & $\begin{array}{l}1.68 \\
0.22\end{array}$ \\
\hline 3112 & 0.17 & $\begin{array}{l}0.20 \\
2.48\end{array}$ & 3219 & 0.84 & $\begin{array}{l}2.71 \\
0.49\end{array}$ \\
\hline 3113 & 0.91 & $\begin{array}{r}12.08 \\
3.46\end{array}$ & 3231 & 0.92 & $\begin{array}{l}5.87 \\
0.63\end{array}$ \\
\hline 3114 & 0.96 & $\begin{array}{l}2.63 \\
0.30\end{array}$ & 3233 & 0.81 & $\begin{array}{r}-0.15 \\
0.50\end{array}$ \\
\hline 3115 & 0.68 & $\begin{array}{r}-0.67 \\
2.44\end{array}$ & 3311 & 0.52 & $\begin{array}{r}-4.74 \\
8.08\end{array}$ \\
\hline 3116 & 0.5 & $\begin{array}{r}-5.66 \\
5.92\end{array}$ & 3312 & 0.7 & $\begin{array}{r}-0.10 \\
0.66\end{array}$ \\
\hline 3117 & 0.69 & $\begin{array}{l}2.78 \\
1.63\end{array}$ & 3319 & 0.97 & $\begin{array}{l}2.48 \\
0.25\end{array}$ \\
\hline 3119 & 0.84 & $\begin{array}{r}-1.62 \\
1.67\end{array}$ & 3411 & 0.36 & $\begin{array}{l}15.62 \\
10.17\end{array}$ \\
\hline 3131 & 0.68 & $\begin{array}{l}1.84 \\
0.72\end{array}$ & 3412 & 0.89 & $\begin{array}{l}2.88 \\
0.74\end{array}$ \\
\hline 3133 & 0.64 & $\begin{array}{r}-0.88 \\
1.18\end{array}$ & 3419 & 0.84 & $\begin{array}{r}-2.11 \\
0.89\end{array}$ \\
\hline 3211 & 0.95 & $\begin{array}{r}-10.92 \\
2.03\end{array}$ & 3511 & 0.89 & $\begin{array}{l}5.02 \\
2.30\end{array}$ \\
\hline 3212 & 0.9 & $\begin{array}{l}3.36 \\
1.06\end{array}$ & 3512 & 0.61 & $\begin{array}{l}0.74 \\
1.03\end{array}$ \\
\hline 3213 & 0.71 & $\begin{array}{r}-1.08 \\
11.42 \\
\end{array}$ & 3513 & 0.78 & $\begin{array}{r}-1.35 \\
2.20 \\
\end{array}$ \\
\hline 3214 & 0.4 & $\begin{array}{l}0.34 \\
4.66\end{array}$ & 3521 & 0.91 & $\begin{array}{r}-0.96 \\
1.02\end{array}$ \\
\hline
\end{tabular}


Table 4 (Cont.)

\begin{tabular}{|c|c|c|c|c|c|}
\hline Ind & Adj. $R^{2}$ & IDIODEM & Ind & Adj. $\mathrm{R}^{2}$ & IDIODEM \\
\hline 3522 & 0.8 & $\begin{array}{r}-0.43 \\
1.71\end{array}$ & 3831 & 0.96 & $\begin{array}{r}-1.88 \\
0.57\end{array}$ \\
\hline 3523 & 0.9 & $\begin{array}{r}12.95 \\
4.35\end{array}$ & 3832 & 0.97 & $\begin{array}{r}13.45 \\
1.54\end{array}$ \\
\hline 3529 & 0.77 & $\begin{array}{l}2.52 \\
1.71\end{array}$ & 3833 & 0.88 & $\begin{array}{l}2.04 \\
0.87\end{array}$ \\
\hline 3691 & 0.71 & $\begin{array}{r}-0.27 \\
0.45\end{array}$ & 3839 & 0.7 & $\begin{array}{r}-0.83 \\
1.53\end{array}$ \\
\hline 3692 & 0.52 & $\begin{array}{r}-1.06 \\
0.90\end{array}$ & 3841 & 0.71 & $\begin{array}{l}0.44 \\
0.95\end{array}$ \\
\hline 3699 & 0.96 & $\begin{array}{l}2.45 \\
0.43\end{array}$ & 3843 & 0.9 & $\begin{array}{l}4.68 \\
3.74\end{array}$ \\
\hline 3811 & 0.83 & $\begin{array}{l}0.25 \\
0.81\end{array}$ & & & \\
\hline 3812 & 0.9 & $\begin{array}{l}1.50 \\
0.82\end{array}$ & & & \\
\hline 3813 & 0.71 & $\begin{array}{l}1.15 \\
1.48\end{array}$ & & & \\
\hline 3819 & 0.92 & $\begin{array}{l}4.03 \\
1.12\end{array}$ & & & \\
\hline 3821 & 0.94 & $\begin{array}{r}-0.63 \\
0.44\end{array}$ & & & \\
\hline 3822 & 0.69 & $\begin{array}{l}1.82 \\
0.96\end{array}$ & & & \\
\hline 3823 & 0.93 & $\begin{array}{l}1.23 \\
1.25\end{array}$ & & & \\
\hline 3824 & 0.88 & $\begin{array}{l}0.13 \\
2.05\end{array}$ & & & \\
\hline 3825 & 0.77 & $\begin{array}{r}-7.49 \\
4.36\end{array}$ & & & \\
\hline 3829 & 0.85 & $\begin{array}{l}3.81 \\
1.48\end{array}$ & & & \\
\hline
\end{tabular}



Table 5

Industry-Pooled Estimation

(Standard errors below estimates)

\begin{tabular}{|c|c|c|}
\hline Industry & IDIODEM & Obs. \\
\hline \multirow[t]{2}{*}{ Food Products } & 2.51 & 104 \\
\hline & 0.28 & \\
\hline \multirow[t]{2}{*}{ Beverage Industries } & 1.11 & 26 \\
\hline & 0.61 & \\
\hline \multirow[t]{2}{*}{ Textiles } & 1.79 & 78 \\
\hline & 0.20 & \\
\hline \multirow[t]{2}{*}{ Leather } & 2.17 & 26 \\
\hline & 0.39 & \\
\hline \multirow[t]{2}{*}{ Wood Products } & 2.16 & 39 \\
\hline & 0.23 & \\
\hline \multirow[t]{2}{*}{ Paper and Pulp } & 0.89 & 39 \\
\hline & 0.57 & \\
\hline \multirow[t]{2}{*}{ Industrial Chems } & 1.02 & 39 \\
\hline & 0.86 & \\
\hline \multirow[t]{2}{*}{ Other chemicals } & 0.28 & 52 \\
\hline & 0.77 & \\
\hline $\begin{array}{l}\text { Other non-metallic } \\
\text { mineral products }\end{array}$ & $\begin{array}{l}0.91 \\
0.30\end{array}$ & 39 \\
\hline \multirow[t]{2}{*}{ Fabricated Metals } & 1.49 & 52 \\
\hline & 0.48 & \\
\hline $\begin{array}{l}\text { Machinery, except } \\
\text { electric }\end{array}$ & $\begin{array}{l}0.11 \\
0.36 \\
\end{array}$ & 78 \\
\hline \multirow[t]{2}{*}{ Electrical Mach. } & 0.42 & 52 \\
\hline & 0.44 & \\
\hline \multirow[t]{2}{*}{ Transportation Equip. } & 0.69 & 26 \\
\hline & 0.92 & \\
\hline
\end{tabular}


Table 6

Three-Digit Runs

(Std. Errors Below Estimates)

Number of Observations $=22$

\begin{tabular}{|c|c|c|c|c|c|}
\hline Ind & Adj. $R^{2}$ & IDIODEM & Ind & Adj. $R^{2}$ & IDIODEM \\
\hline 311 & 0.72 & $\begin{array}{l}18.28 \\
17.41\end{array}$ & 355 & 0.82 & $\begin{array}{r}-1.03 \\
1.01\end{array}$ \\
\hline 313 & 0.7 & $\begin{array}{l}0.15 \\
0.45\end{array}$ & 356 & 0.91 & $\begin{array}{l}1.32 \\
0.20\end{array}$ \\
\hline 314 & 0.69 & $\begin{array}{l}0.81 \\
0.29\end{array}$ & 361 & 0.64 & $\begin{array}{l}3.05 \\
0.86\end{array}$ \\
\hline 321 & 0.83 & $\begin{array}{l}62.64 \\
20.35\end{array}$ & 362 & 0.84 & $\begin{array}{l}0.71 \\
1.11\end{array}$ \\
\hline 322 & 0.85 & $\begin{array}{r}-0.53 \\
0.18\end{array}$ & 369 & 0.74 & $\begin{array}{l}1.61 \\
0.72\end{array}$ \\
\hline 323 & 0.2 & $\begin{array}{r}-0.32 \\
0.80\end{array}$ & 371 & 0.81 & $\begin{array}{l}3.42 \\
1.98\end{array}$ \\
\hline 324 & -0.03 & $\begin{array}{r}-0.12 \\
0.44\end{array}$ & 372 & 0.86 & $\begin{array}{r}-0.09 \\
1.35\end{array}$ \\
\hline 331 & 0.69 & $\begin{array}{l}0.70 \\
0.40\end{array}$ & 381 & 0.84 & $\begin{array}{r}-0.33 \\
0.78\end{array}$ \\
\hline 332 & 0.65 & $\begin{array}{l}0.56 \\
0.90\end{array}$ & 382 & 0.92 & $\begin{array}{r}-5.40 \\
2.48\end{array}$ \\
\hline 341 & 0.59 & $\begin{array}{r}-1.07 \\
1.05\end{array}$ & 383 & 0.71 & $\begin{array}{r}-1.81 \\
4.56\end{array}$ \\
\hline 342 & 0.76 & $\begin{array}{l}12.94 \\
10.35\end{array}$ & 384 & 0.91 & $\begin{array}{l}1.42 \\
1.25\end{array}$ \\
\hline 351 & 0.91 & $\begin{array}{r}-0.61 \\
0.45\end{array}$ & 385 & 0.8 & $\begin{array}{l}2.95 \\
2.15\end{array}$ \\
\hline 352 & 0.88 & $\begin{array}{l}0.71 \\
1.14\end{array}$ & & & \\
\hline 353 & 0.82 & $\begin{array}{r}-1.28 \\
0.40\end{array}$ & & & \\
\hline
\end{tabular}


Table 7

\section{Beta Coefficients (four-digit)}

Industry

Slaughtering, preparing and preserving meat

Canning and preserving of fruits and vegetables

Canning, preserving, and processing of seafood

Bakery products

Distilling, rectifying and blending spirits

Made-up textile goods except wearing apparel

Knitting mills

Textiles nec

Tanneries and leather finishing

Wood and cork products nec

Pulp, paper and paperboard

Containers and boxes of paper and paperboard

Basic industrial chemicals except fertilizer

Soap and cleaning preparations, perfumes, and cosmetics

Chemical products nec

Non-metallic mineral products nec

Furniture and fixtures primarily of metal

Structural metal products

Fabricated metal products

Agricultural machinery and Equipment

Metal and wood working machinery

Machinery and equipment, except electrical nec

Radio, television and communication equipment

Electrical appliances and housewares

Motor vehicles

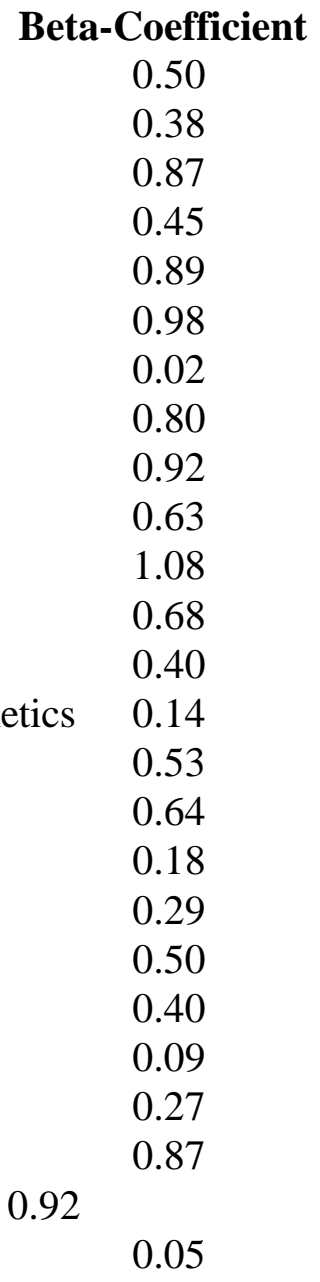




\title{
Appendix I: Industries Used in the Analysis
}

\author{
Dropped (X)ISIC \\ 311 \\ 3111 \\ 3112 \\ 3113 \\ 3114 \\ 3115 \\ 3116 \\ 3117 \\ X 3118 \\ 3119 \\ 312 \\ X 3121 \\ X 3122 \\ 313 \\ 3131 \\ X \\ 3132 \\ 3133 \\ X $\quad 3134$ \\ X
X14 \\ 321 \\ 3211 \\ 3212 \\ 3213 \\ 3214 \\ 3215 \\ 3219 \\ X \\ X \\ 3232 \\ 3233 \\ X $\quad 324$
I \\ 331 \\ 3311 \\ 3312 \\ 3319 \\ X \\ 332 \\ Industry \\ Food products \\ Slaughtering, preparing and preserving meat \\ Dairy products \\ Canning and preserving of fruits and vegetables \\ Canning, preserving and processing of fish, crustacea and similar foods \\ Vegetable and animal oils and fats \\ Grain mill products \\ Bakery products \\ Sugar factories and refineries \\ Cocoa, chocolate and sugar confectionery \\ Other food products \\ Food products not elsewhere classified \\ Prepared animal feeds \\ Beverage industries \\ Distilling, rectifying and blending spirits \\ Wine industries \\ Malt liquors and malt \\ Soft drinks and carbonated waters industries \\ Tobacco manufactures \\ Textiles \\ Spinning, weaving and finishing textiles \\ Made-up textile goods except wearing apparel \\ Knitting mills \\ Carpets and rugs \\ Cordage, rope and twine industries \\ Textiles nec \\ Wearing apparel, except footwear \\ Leather and products of leather, leather substitutes and fur, except footwear and \\ wearing apparel \\ Tanneries and leather finishing \\ Fur dressing and dyeing industries \\ Products of leather and leather substitutes, except footwear and wearing apparel \\ Footwear, except vulcanized or molded rubber or plastic footwear \\ Wood and wood and cork products, except furniture \\ Sawmills, planing and other wood mills \\ Wooden and cane containers and small cane ware \\ Wood and cork products nec \\ Furniture and fixtures, except primarily of metal
}




\section{Appendix I (Continued)}

\section{Industries Used in the Analysis}

\begin{tabular}{|c|c|c|}
\hline Dropped $(\mathrm{X})$ & $\begin{array}{l}\text { ISIC } \\
341\end{array}$ & $\begin{array}{l}\text { Industry } \\
\text { Paper and paper products }\end{array}$ \\
\hline & $\begin{array}{l}3411 \\
3412 \\
3419\end{array}$ & $\begin{array}{l}\text { Pulp, paper and paperboard } \\
\text { Containers and boxes of paper and paperboard } \\
\text { Pulp, paper and paperboard articles nec }\end{array}$ \\
\hline$X$ & $\begin{array}{l}342 \\
351 \\
3511 \\
3512 \\
3513\end{array}$ & $\begin{array}{l}\text { Printing, publishing and allied industries } \\
\text { Plastic Products } \\
\text { Industrial chemicals } \\
\text { Basic industrial chemicals except fertilizer } \\
\text { Fertilizers and pesticides } \\
\text { Synthetic resins, plastic materials and man-made fibers except glass }\end{array}$ \\
\hline & $\begin{array}{l}352 \\
3521 \\
3522 \\
3523 \\
3529\end{array}$ & $\begin{array}{l}\text { Other chemical products } \\
\text { Paints, varnishes and lacquers } \\
\text { Drugs and medicines } \\
\text { Soap and cleaning preparations, perfumes, cosmetics and other toilet preps. } \\
\text { Chemical products nec }\end{array}$ \\
\hline $\mathrm{X}$ & 353 & Petroleum refineries \\
\hline $\mathrm{X}$ & 354 & Miscellaneous products of petroleum and coal \\
\hline$X$ & $\begin{array}{l}355 \\
3551 \\
3559\end{array}$ & $\begin{array}{l}\text { Rubber products } \\
\text { Tire and tube industries } \\
\text { Rubber products nec }\end{array}$ \\
\hline $\mathrm{X}$ & 356 & Plastic products nec \\
\hline $\mathrm{X}$ & 361 & Pottery, china and earthenware \\
\hline $\mathrm{X}$ & $\begin{array}{l}362 \\
369 \\
3691 \\
3692 \\
3699\end{array}$ & $\begin{array}{l}\text { Glass and glass products } \\
\text { Other non-metallic mineral products } \\
\text { Structural clay products } \\
\text { Cement, lime and plaster } \\
\text { Non-metallic mineral products nec }\end{array}$ \\
\hline $\mathrm{X}$ & 371 & Iron and steel basic industries \\
\hline $\mathrm{X}$ & 372 & Non-ferrous metal basic industries \\
\hline
\end{tabular}




\section{Appendix I (Continued)}

\section{Industries Used in the Analysis}

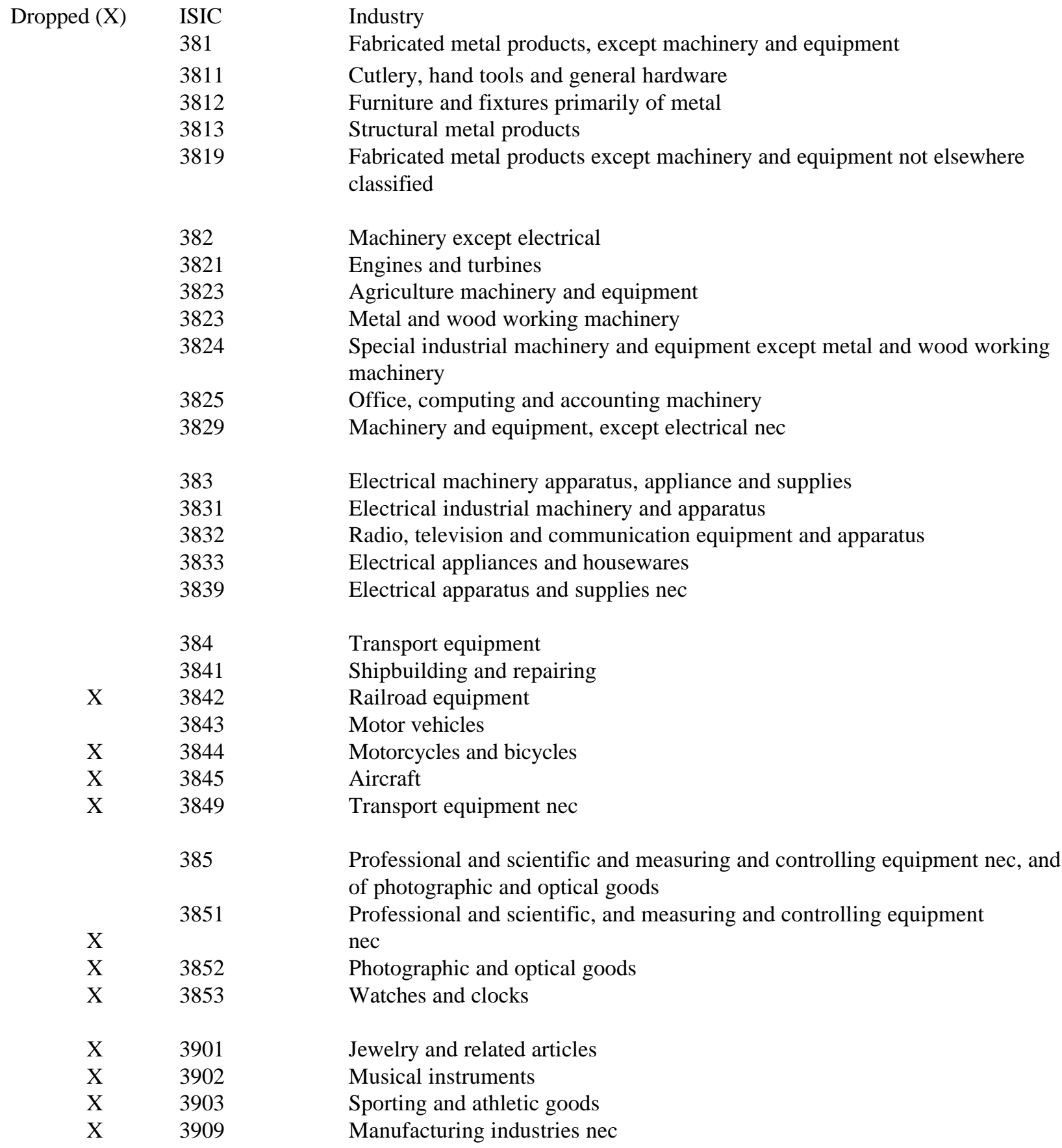


Figure 1

Implementing a Symmetric Geography
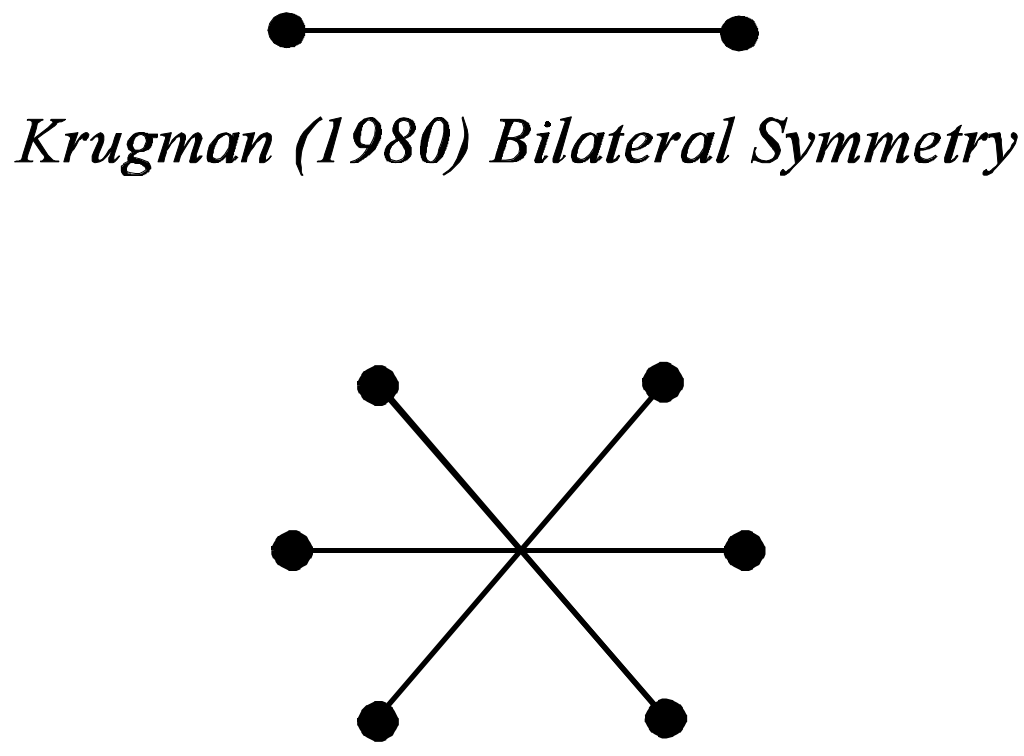

Symmetric Hub-and-Spoke 
Figure 2

Implementing an Asymmetric Geography

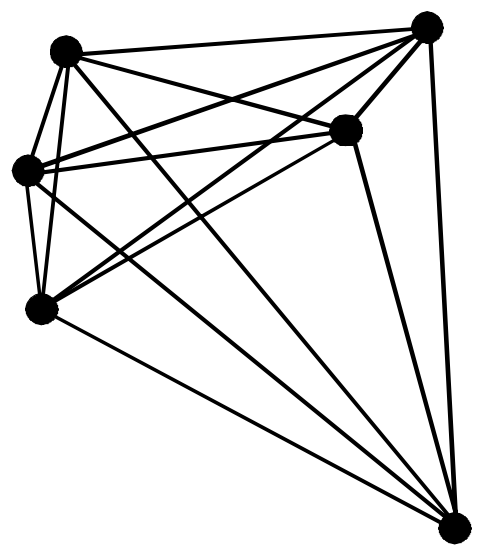

An Asymmetric Gravity-Based Model 
Figure 3

\section{The Helpman-Krugman Model of Economic Geography}

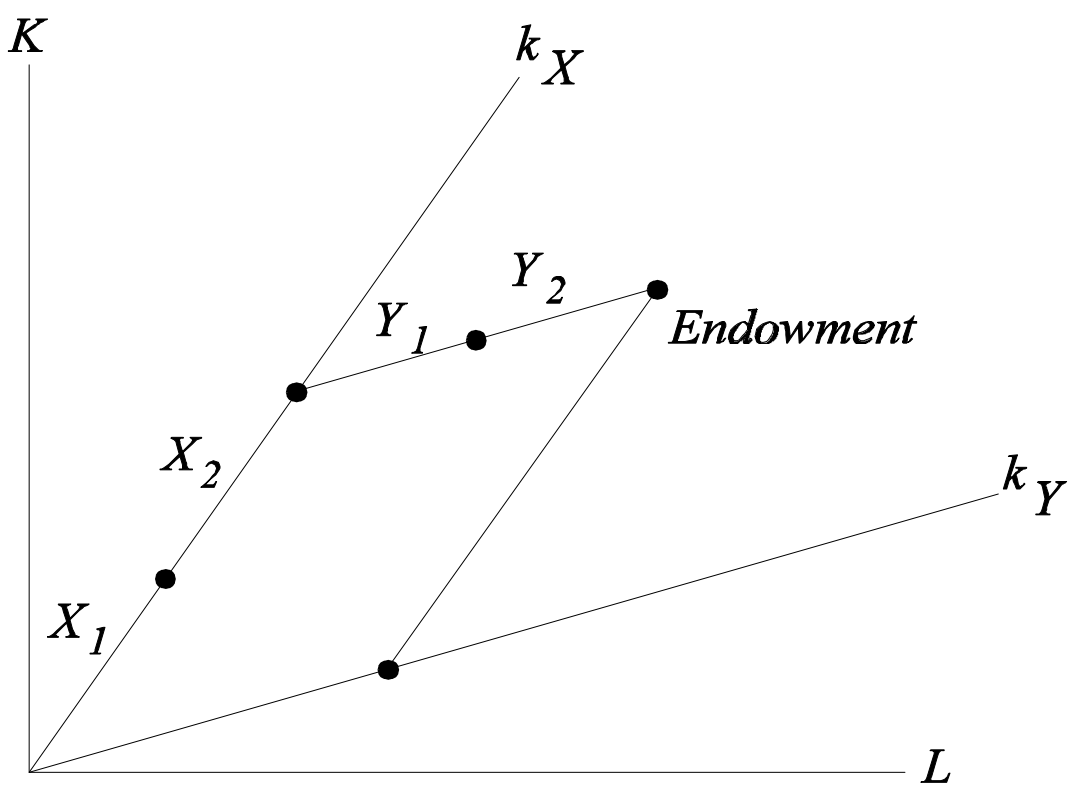


Figure 4

Gravity- vs. Country-Based Demand Deviations

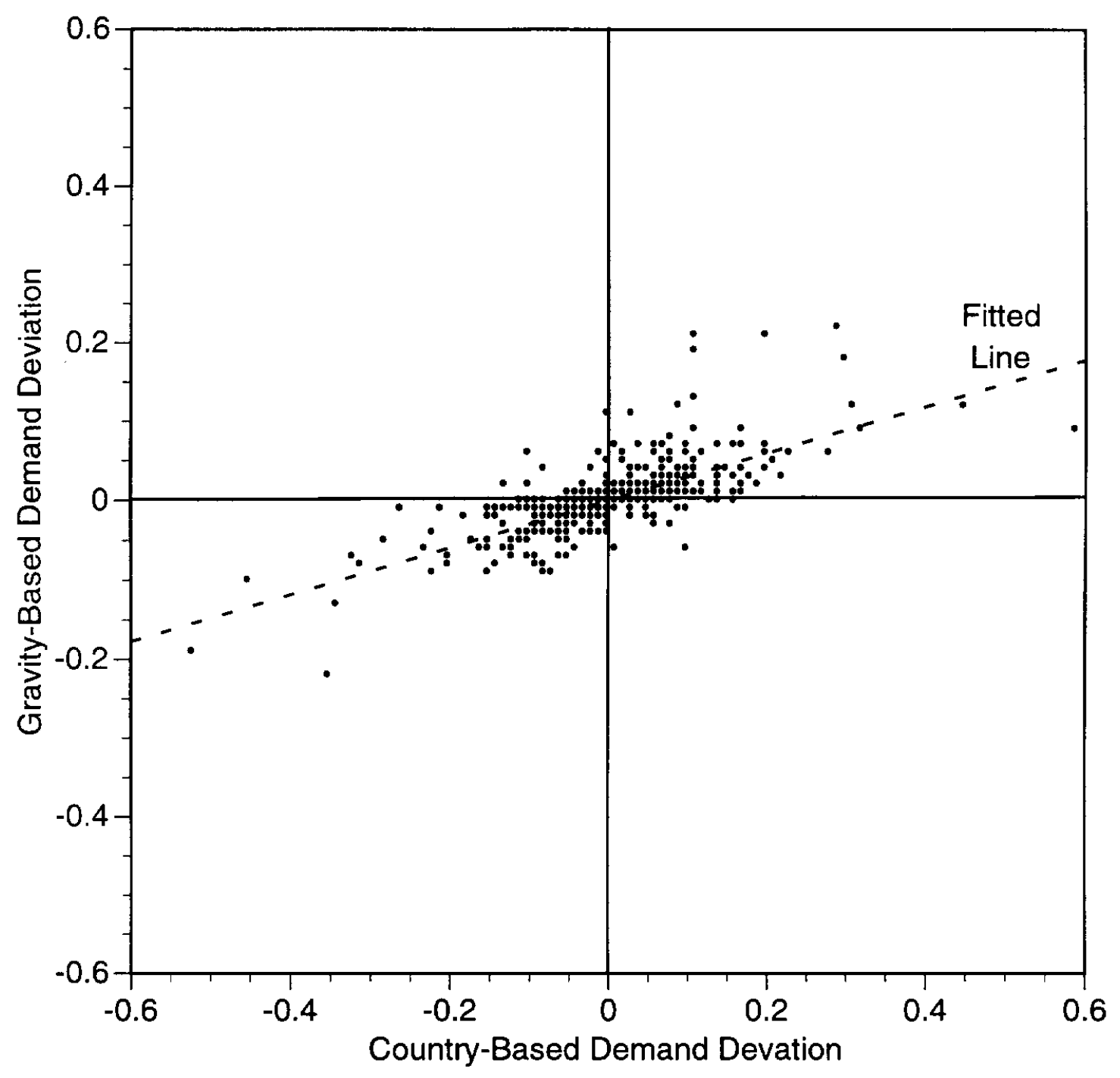

Note: The Idiosyncratic Demand Deviation is the share of 4-digit absorption in 3-digit absorption less that level for the rest of the world, i.e. $\delta_{g}^{n c}-\delta_{g}^{n R O W}$. The "country-based" deviation calculates the demand deviation for a particular country by only using demand data from that country in constructing the demand deviation. It is identical to the measure used in Davis and Weinstein (1996). The "gravitybased" deviation calculates this deviation based on a weighted average of all countries. These weights are based on the gravity equation. 
Figure 5

Impact of Switching From Country-Based Demand to Gravity-Based Demand on the Demand Deviation Variable

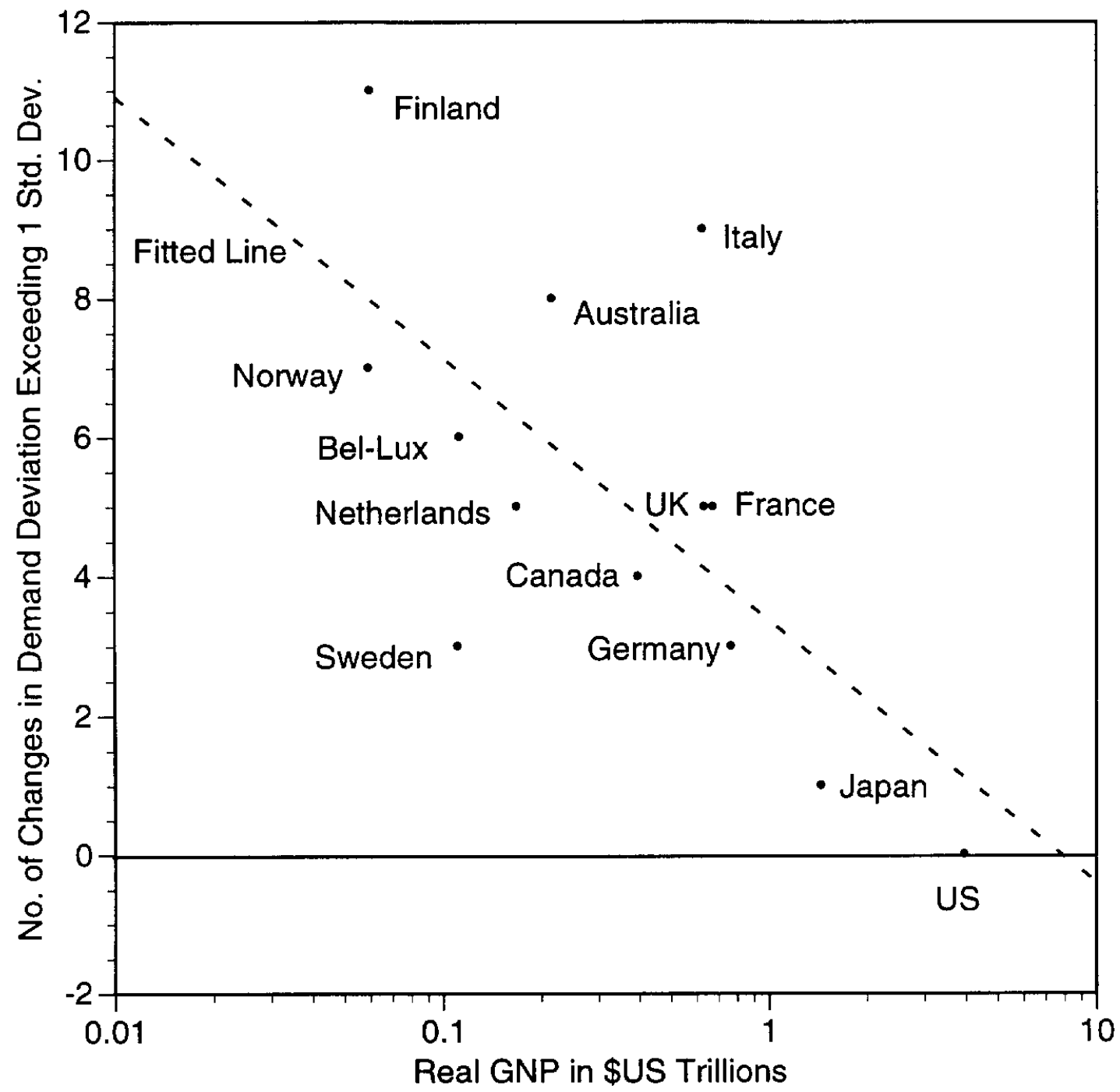

Note: This figure shows how the demand deviation variable was transformed by switching from using country-based demand to gravity-based demand. The number of times the two variables differed by more than one standard deviation (calculated using the country-based demand variable) is plotted against the country's GNP. The figure shows that this transformation affects small countries far more than large countries. 
Figure 6

Production Deviation vs. Demand Deviation

(3 and 4 Digit Data)

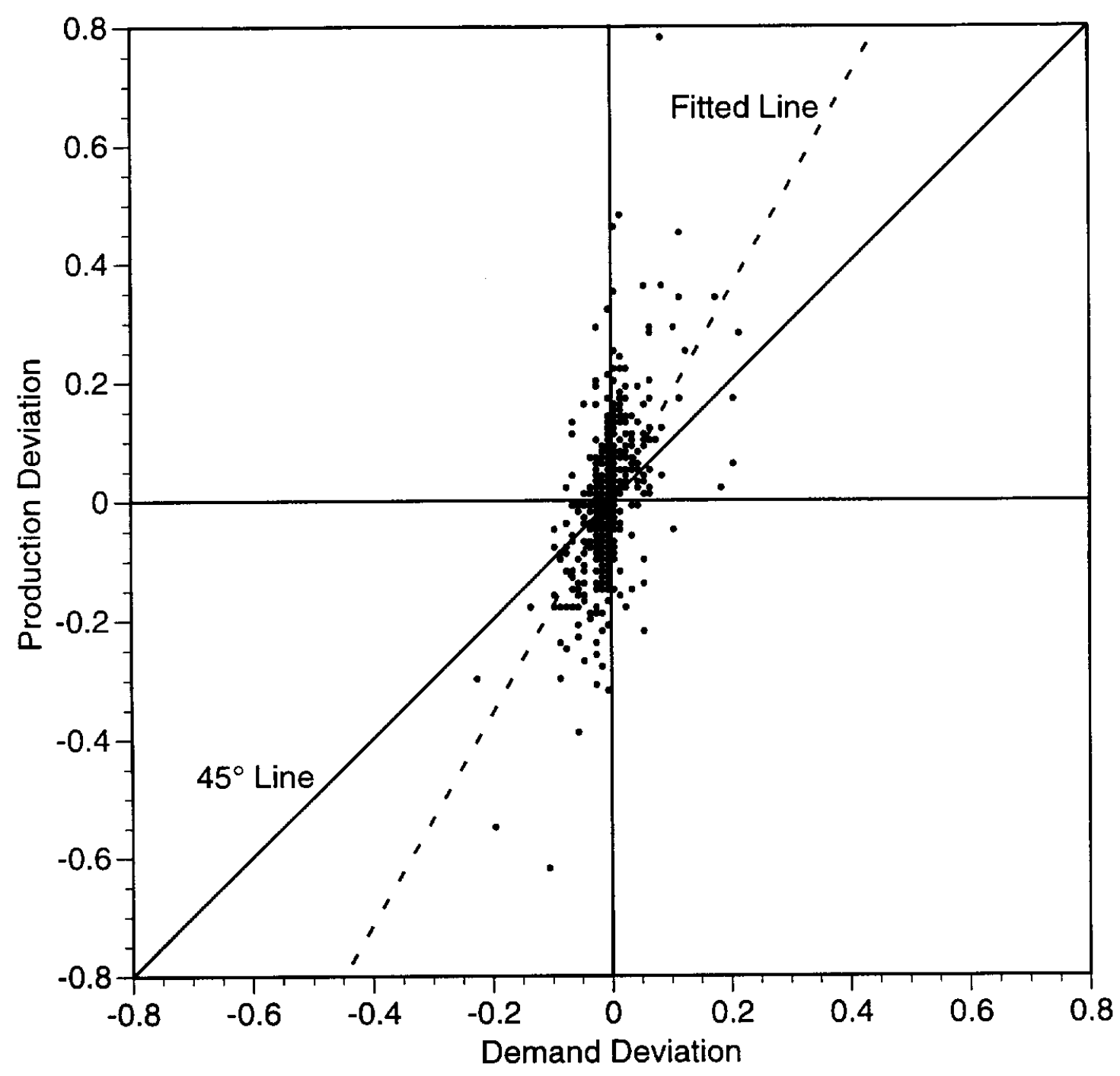

Note: The Idiosyncratic Demand Deviation is the share of 4-digit absorption in 3-digit absorption less that level for the rest of the world, i.e. $\delta_{g}^{n c}-\delta_{g}^{n R O W}$. The Production Deviation is the share of 4-digit output in a 3-digit industry less that level for the rest of the world, i.e. $\gamma_{g}^{n c}-\gamma_{g}^{n R O W}$. These variables indicate how different absorption and production are from the rest of the world. 